\title{
Bona i Bredestad - från en vikingatida storgård till en medeltida huvudgård
}

\section{Inledning}

Den bördiga Bredestadsdalen i norra Småland är en gammal kulturbygd och ett kommunikativt nav på sydsvenska höglandet. På gården Bonas ägor i södra delen av dalgången har välbevarade gårdslämningar från yngre järnåldern undersökts arkeologiskt (figur 1). Dessa ligger strax intill Bredestad medeltida sockenkyrka och visar att en större gård etablerades här under 600-talet e.Kr., på en plats som tidigare inte varit bebyggd. I slutet av 900-talet eller början av 1000-talet raserades den vikingatida bebyggelsen och gården synes ha flyttat till Bonas historiska tomt, som fortfarande är bebyggd (för periodindelningar, se tabell 1). Huvudbyggnaden var manifest och låg avskild från gårdens ekonomidel. En agrarhistorisk analys visar att Bona varit huvudgård i ett medeltida godskomplex. Vi kommer i det följande att argumentera för att gården ska ses som en storgård, som framför allt varit viktig ur ett lokalt perspektiv. En övergripande fråga är om det går att belägga kontinuitet i jordägande mellan yngre järnåldersgården och den medeltida huvudgården. I artikeln problematiseras även gårdens etablering.

Under senare år har flera av de större vägarna i dalgången dragits om, och ett flertal arkeologiska undersökningar av varierande karaktär och omfattning har utförts. Dessa berörde flera större landskapsutsnitt; delar av agrarlandskapet med rötter i förhistorisk tid, men också förhistoriska bebyggelseplatser (Vestbö 1994; Enbäck och Vestbö-Franzén 1996; Engman 1999; Jansson och Nordström 2000; Borg och Engman 2003; Vestbö 2006). I denna artikel ligger fokus på en gård från vendel- och vikingatid med elitbetonade drag som berörts av upprepade arkeologiska undersökningar (Jansson och Kristensson 2004; Jansson och Rödjer 2014; Sjölin 2014, 2016). Under 2000 undersöktes de västra delarna av gården där huvudbyggnaden legat (Jansson och Kristensson 2004). Under 2014 undersöktes de östra delar av gården med ytterligare bostadshus och ekonomibyggnader (Sjölin 2016). I samband med detta upprättades ett pollendiagram (Lagerås 2016) och en agrarhistorisk analys av historiskt källmaterial och äldre kartor genomfördes (Ericsson 2016). Den senare visar att det under äldre medeltid (1050-1350) funnits huvudgårdar och godskomplex i Bredestadsdalens södra delar. Arbetet med denna artikel har inneburit att materialet infogats i en större kontext och att delar av materialet givits en ny tolkning. 


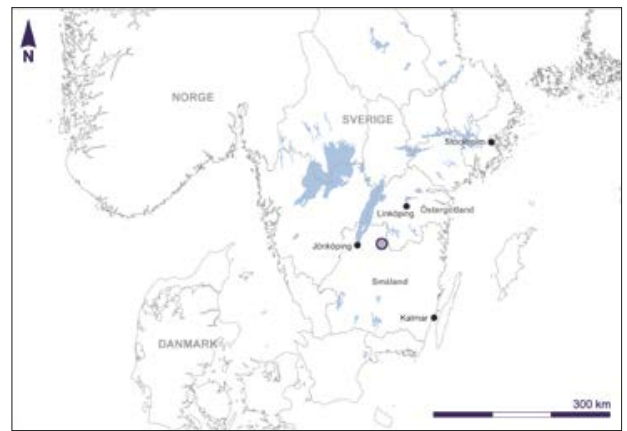

Figur 1. Läget för de arkeologiska undersökningarna markerat på utsnitt ur Terrängkartan, blad 557 Tranås (skala 1:50 000), och Sverigekartan. Kartunderlag: Geografiske Sverigedata (GSD) Sverigekartan och GSD Terrängkartan. Illustration: Henrik Pihl, Arkeologerna, Statens historiska museer.

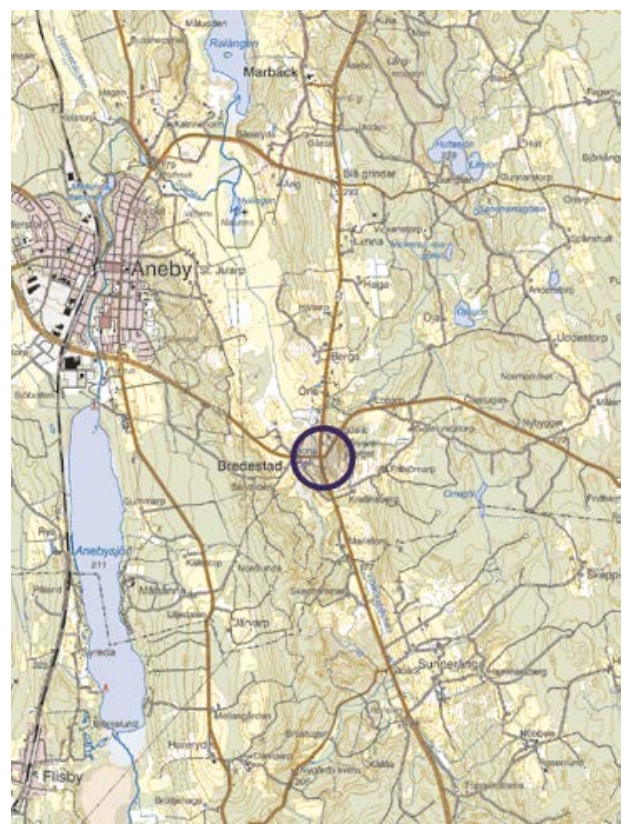

En utgångspunkt i artikeln är ett landskapsanalytiskt ramverk, som binder ihop de olika källmaterialen. Detta kombineras med detaljerade analyser av enskildheter. Kombinationen av makro- och mikronivå har tidigare visat sig mycket fruktbar (jfr. till exempel Hansen 2015). Metodiskt har analysen av platsen varit intressant att genomföra, då historiskt källmaterial har bidragit med information som relaterar till yngre järnålderns förhållanden.

\section{Problemställningar och teoretiskt ramverk}

Denna artikel syftar till att undersöka makt, Tabell 1. Tabellen visar de periodbeteckningar som används $i$ artikeln.

\begin{tabular}{|l|l|}
\hline Äldre järnålder & 500 f.Kr.-400 e.Kr. \\
\hline Förromersk järnålder & 500 f.Kr.-Kr.f. \\
\hline Äldre romersk järnålder & Kr.f.-200 e.Kr. \\
\hline Yngre romersk järnålder & $200-400$ e.Kr. \\
\hline Yngre järnålder & $400-1050$ e.Kr. \\
\hline Folkvandringstid & $400-550$ e.Kr. \\
\hline Vendeltid & $550-800$ e.Kr. \\
\hline Vikingatid & $800-1050$ e.Kr. \\
\hline Medeltid & $1050-1520$ e.Kr. \\
\hline Äldre Medeltid & $1050-1350$ e.Kr. \\
\hline Högmedeltid & $1200-1350$ e.Kr. \\
\hline Senmedeltid & $1350-1520$ e.Kr. \\
\hline
\end{tabular}
maktens uttryck och jordägande på en lokal nivå under perioden vendel- och vikingatid samt äldre medeltid genom en landskapsanalys, där det långa tidsperspektivet är av central betydelse. I artikeln problematiseras etableringen av en ny elitbetonad gård där läge i landskapet, markanvändning, ekonomi och elitens maktanspråk är några variabler som diskuteras. Ytterligare en central fråga i artikeln är om det går att belägga kontinuitet eller diskontinuitet mellan vikingatid och äldre medeltid vad gäller en jordegendom i södra delen av Bredestadsdalen och därmed om det föreligger kontinuitet eller diskontinuitet vad gäller elit 
och ägande. Om kontinuitet mellan järnålder och medeltid kan beläggas betyder det att här öppnas en möjlighet att få information rörande storleken på det ägoområde som tillhört en elitär bosättning från yngre järnålder.

I studien kombineras ett mångfacetterat material som tar utgångspunkt i källor som är fristående från varandra. För det första används ett arkeologiskt material, vilket tolkas med utgångspunkt i forskning rörande yngre järnålderns centralplatser (till exempel Callmer och Rosengren 1997; Hårdh 2001; Söderberg 2003; Jørgensen 2010). För det andra används äldre kartor, skriftliga källor och ortnamn, vilka tolkas i en agrarhistorisk och kulturgeografisk tradition (Rahmqvist 1996; Tollin 1999; Berg 2003a; Ericsson 2012; Karsvall 2016). Ett tredje material i studien är pollenanalys, som bidragit med ett landskapshistoriskt sammanhang där särskilt samspelet mellan människa och landskap belyses (Lagerås 1996, 2007, 2016).

Ett modernt landskapsteoretiskt perspektiv, som till sin natur är tvärvetenskapligt, bildar ett ramverk för studien i sin helhet (jfr. Ashmore och Knapp 1999; Berg 2003a). Landskapsperspektivet kombineras med det långa tidsperspektivet, där särskilt mer trögrörliga strukturer lämnar spår i landskapet (Carelli 2001:13). Ett komplement till det långa tidsperspektivet är ett aktörs- eller handlingsperspektiv med fokus på enskilda handlingar, vilka även dessa har lämnat spår i landskapet (Bell 1992).

Inom kulturgeografisk och historisk forskning har begreppet storgårdsdrift använts för en speciell produktionsform, där storgården drevs med slavarbetskraft, vilken kombinerades med extern tillägnelse via plundring och tributtagande (Schmidt Sabo m.fl. 2011:42 och där anförd litteratur). Dessa variabler kan svårligen beläggas med hjälp av arkeologiskt material. Vi har ändå valt att omtala den undersökta gården i Bona som en storgård och i den definitionen har vi valt att särskilt utgå från gårdens rumsliga utformning och arkitektur i kombination med fyndmaterial, läge i landskapet och liknande. Vår uppfattning om vad som är möjligt utifrån ett arkeologiskt material ansluter sig därmed till andra forskares (Schmidt Sabo m.fl. 2011:43)

\section{Södra Bredestadsdalen - landskap och kulturhistoria}

I det följande ges en kulturhistorisk översikt av det aktuella landskapsrummet. Norra delen av sydsvenska höglandet karaktäriseras av omväxlande markanta höjdsträckningar med mäktiga moränlager, vilka når nivåer över 400 m över havet, samt mellan dem dalar med sjöar, vattendrag och sankmarker. Den undersökta storgården från yngre järnålder ligger på ägor tillhörande gården Bona i Bredestads socken i norra Småland (figur 2). Bona ligger i direkt anslutning till sockenkyrkan, i södra delen av Bredestadsdalen som är en sydlig förlängning av sjön Ralången. Dalgången begränsas av markanta sluttningar i såväl öster som väster. Dalgångens botten har i äldre tider företrädesvis använts som slåttermark, medan högre belägna avsatser brukats som åker. Ytterligare högre upp i terrängen har betesmarker och skog tagit vid. Svartån flyter genom Bredestadsdalen och den är en gammal kommunikationsled mellan Östergötlands slättbygd i norr och de mindre kulturbygder som utmärker sydsvenska höglandet i söder. I botten av Bredestadsdalen flyter Vibäckabäcken mot norr. Vattendraget passerar gården Bona innan det mynnar ut i Svartån.

Strax norr om ägogränsen till Bona, på grannbyn Örles marker, finns två stora gravfält. Det ena rymmer över hundra gravar, varav 17 höga och en möjlig treudd, medan resten är 


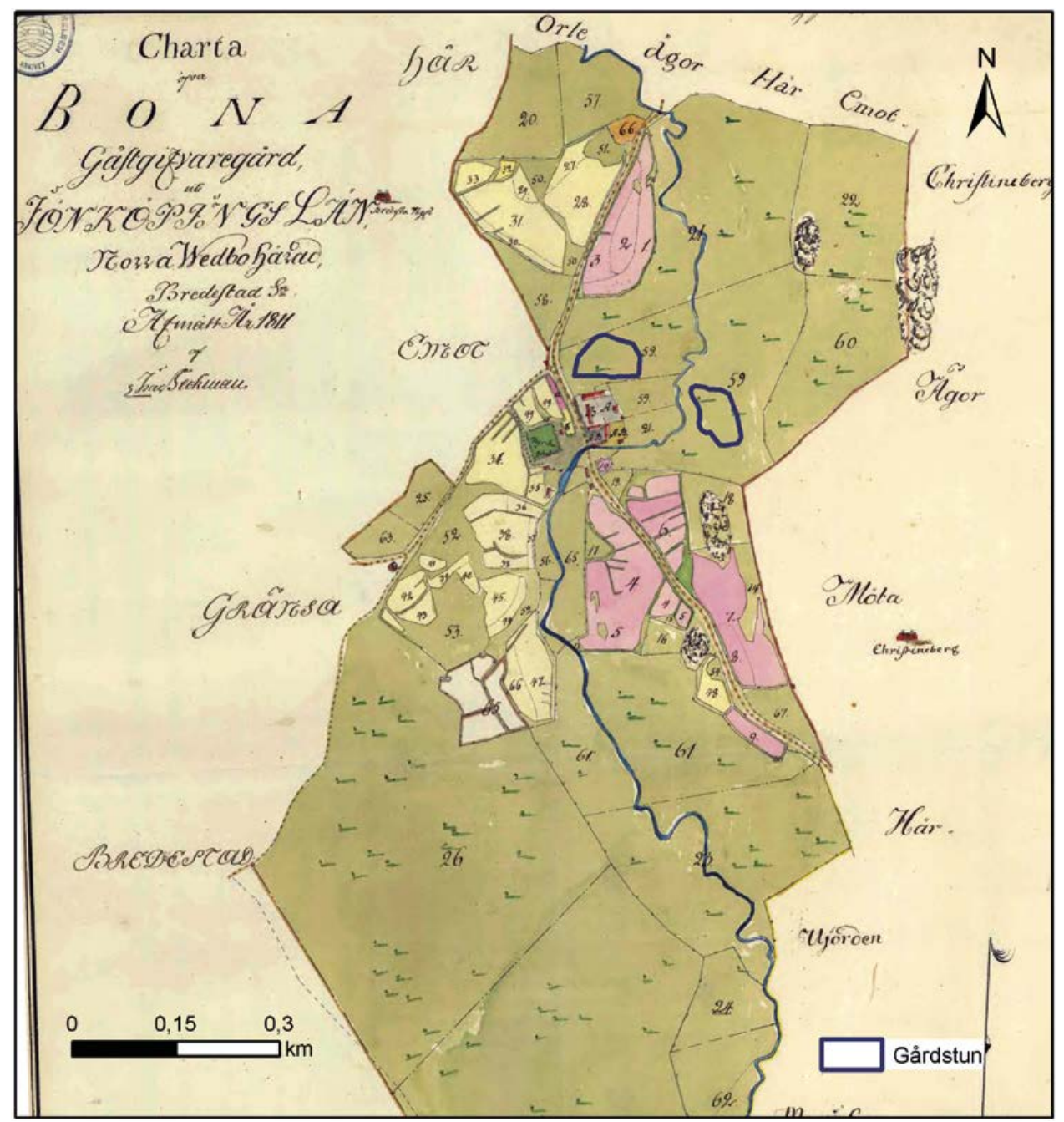

Figur 2. Läget för den tudelade vikingatida tomten markerat på storskifteskarta över Bona $i$ Bredestad socken 1811. Efter Lantmäteristyrelsens arkiv (LSA 2018:Akt E18-5:1). Illustration: Marita Sjölin, Arkeologerna, Statens historiska museer.

runda stensättningar. Huvudsakligen torde gravfältet vara från yngre järnålder (figur 3). Det andra gravfältet är högre beläget i terrängen och har gravtyper som pekar mot en datering till äldre och mellersta järnålder. Gravarna utgörs av sju domarringar och 13 runda stensättningar (figur 4). De båda gravfälten bildar troligen en kronologisk kedja. Örle var på 1500talet en liten by med två gårdar och kan knappast vara upphovet till dessa stora gravfält. Troligt är att det yngre gravfältet hör samman med vikingatidens storgård i Bredestad (Bona). 


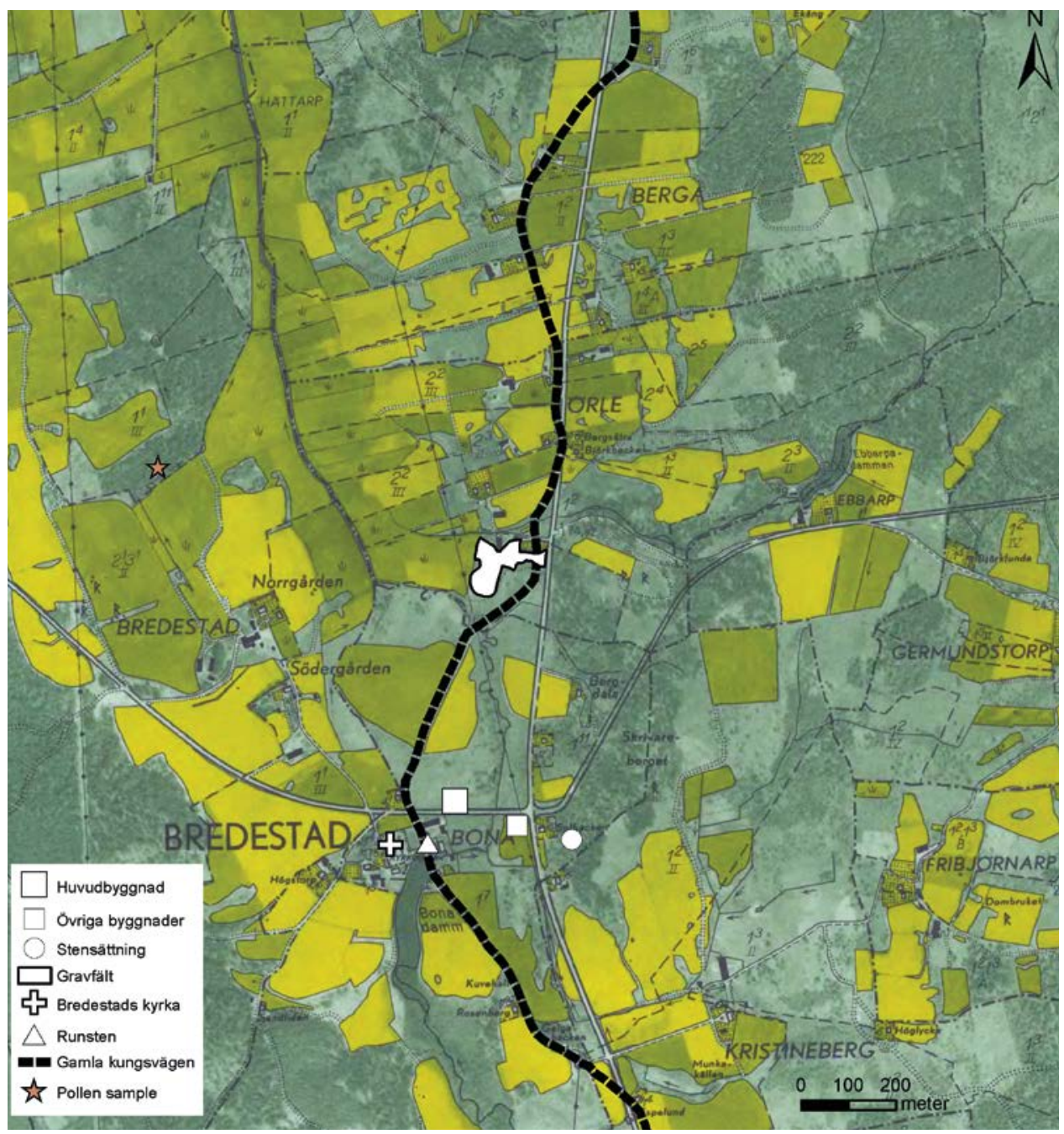

Figur 3. Fornlämningsbild i södra Bredestad under vendeltid och vikingatid, 650-1000 e.Kr. Under perioden koncentreras lämningarna till dalbottnen. Skala 1:15 000. Efter Riksantikvarieämbetets fornminnesinformationssystem (FMIS) (2018) och Rikets allmänna kartverks arkiv (RAK) (2018). Illustration: Marita Sjölin, Arkeologerna, Statens historiska museer.

Den äldsta bevarade kartan över Bona är från 1811 (Lantmäteristyrelsens arkiv [LSA] 2018:Akt E18-5:1). Då fanns endast en gård, närmare bestämt ett gästgiveri, inom denna registerenhet. Detta förhållande kan spåras tillbaka åtminstone till 1500-talet. Bona särredovisas nämligen i kronans jordeböcker från Gustav Vasas regeringstid (Smålands handlingar [SmH] 2018:1539:9, 1540:6). Det fanns då endast en bonde och därmed en gård i Bona (jfr. figur 2). Bredestads kyrka ligger inom Bonas ägoområde, endast $50 \mathrm{~m}$ öster om 


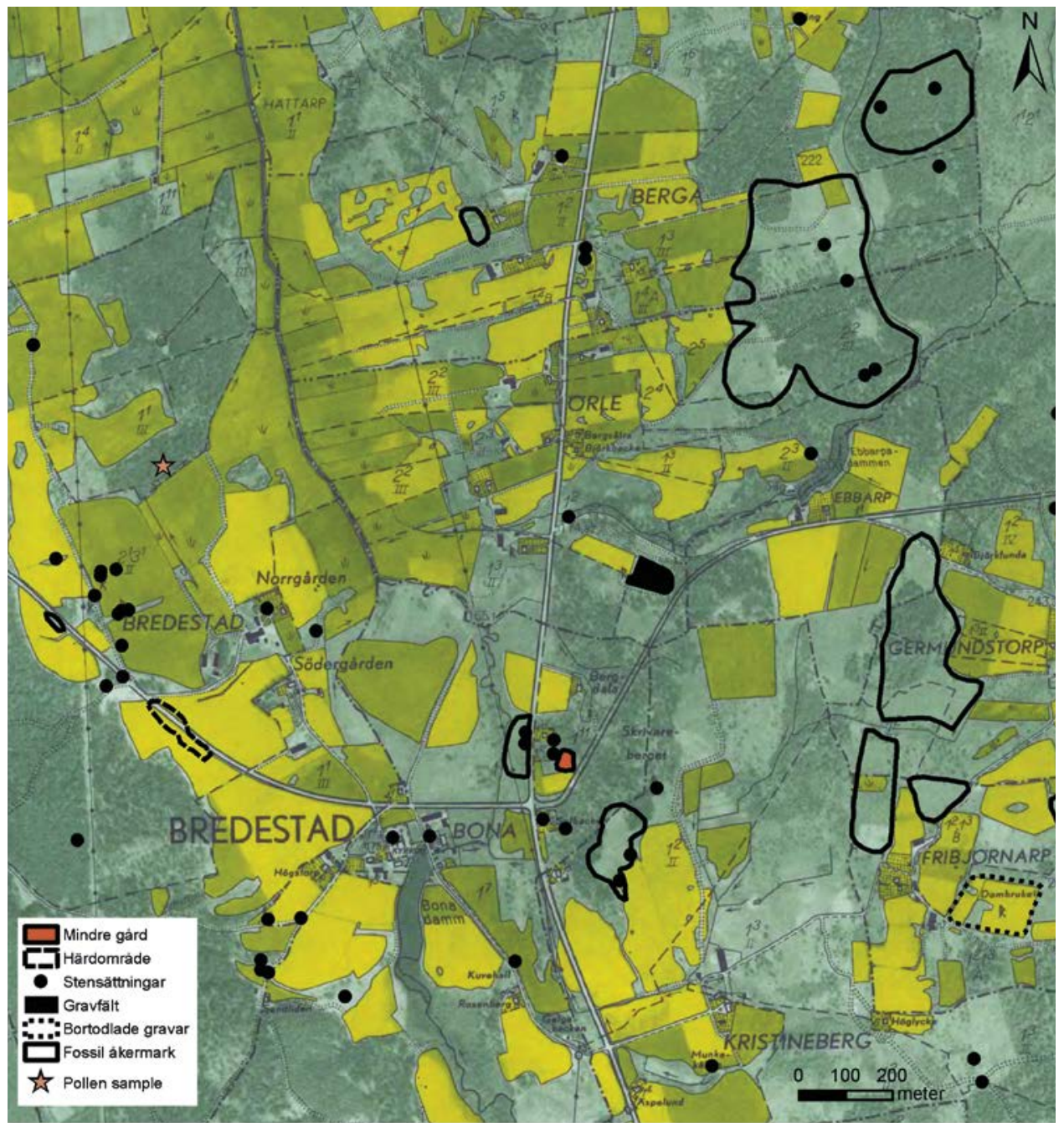

Figur 4. Fornlämningsbild i södra Bredestad under äldre järnålder, 500 f.Kr.-400 e.Kr. Under perioden finns lämningar $i$ hela området, både i dalgången och på dess sidor och höjder. Skala 1:15 000. Efter FMIS (2018) och RAK (2018). Illustration: Marita Sjölin, Arkeologerna,

Statens historiska museer.

gårdstomten och åtskild från denna av en väg. Kyrkan är en romansk stenbyggnad av en typ som började uppföras under 1100-talet. Vid undersökningar har dessutom framkommit lämningar som tyder på att det kan ha funnits en äldre träkyrka på platsen (Haltiner Nordström 2010). Vid huvudbyggnaden på nuvarande Bona gård står en runsten, som har sammanfogats av fyra fragment, påträffade på olika ställen i och invid gästgiveribyggnaden. Ingen sammanhängande runslinga är bevarad, varför det inte går att läsa någon sammanhängande 
textrad, men mansnamnet Håkan finns kvar och högst upp skymtar ett kors. Runristningen torde vara från andra hälften av 1000-talet. Antagligen har runstenen rests i närheten av fyndplatsen och den gamla landsvägen, den så kallade Kungsvägen mellan Linköping och Kalmar (Agertz och Varenius 2002). Vägen finns utsatt på en karta från 1650 (LSA 2018:Akt E7-1:1). Sannolikt fanns vägen långt innan runstenen restes. Möjligen har runstenen rests vid passagen över bäcken. I så fall har den stått i en gräns i landskapet och markerat den plats där man kommit in på gårdstomten (jfr. Zachrisson 1998). På historiska kartor går gränsen för gårdstomten just i bäcken. Bredestad var Vedbo härads tingsplats. Fram mot mitten av 1400-talet delades det ursprungliga häradshövdingedömet i Norra och Södra Vedbo härad (Almquist 1954:350-351). Häradsting omtalas i Bredestad mellan åren 1345 och 1461 (Svensk diplomatariums hovudkartotek över medeltidsbreven [SDHK] 2018:5195, 6742, 7039, 7042, 11922, 19672, 27791). Exakt var tingsplatsen låg är inte känt, men den topografiskt distinkta bergsryggen Skrivareberget inom nuvarande Bonas ägor utpekas av traditionen som den plats varpå tingsförhandlingarna hölls. Likaså säger traditionen att avrättningsplatsen låg utmed landsvägen på en plats som fortfarande benämns Galgbacken, likaså inom nuvarande Bonas ägor.

\section{Pollenanalys}

En pollenstapel från en centralt belägen torvmark i Bredestadsdalens botten har analyserats (Lagerås 2016). I det följande fokuserar vi på resultat som är relevanta för den vendeltida etableringen av gården samt belyser landskapet under vikingatid och äldre medeltid.

I pollendiagrammet (figur 5) framträder 470-1250 e.Kr. som en sammanhängande period. Cirka 500 e.Kr. minskade andelen pollen för flera betesindikatorer, vilket tyder på en tillbakagång i betet. Samtidigt expanderade tallen, sannolikt på de övergivna betesmarkerna. De odlade växterna visar dock, till skillnad från betesindikatorerna, inga tecken på tillbakagång utan odlingen av korn har fortsatt under hela perioden. Från och med 700-tal odlades råg. Från 800-talet indikerar pollenanalysen att våtmarker upprepade gånger har röjts för slåtter, för att senare åter växa igen. Under perioden 1250-1480 e.Kr. ökade gradvis inslaget av kulturmarksväxter. I periodens inledning röjdes återigen våtmarkerna, antagligen för slåtter. På torrare mark utvidgades betesmarkerna, något som speglas i en ökning av gräs- och enpollen på 1200-talet. Bland de odlade växterna fortsatte korn att dominera, kompletterad med sparsam rågodling. Flera andra pollendiagram från denna del av sydsvenska höglandet uppvisar tydliga tecken på ödeläggelse, dels under folkvandringstid på 500-talet, dels under senmedeltid på 1300/1400-talet (Lagerås 1996, 2007). Till skillnad från Bredestad ligger dessa lokaler i mer eller mindre höglänt moränmark. Diagrammet från Bredestad visar däremot odlingskontinuitet, något som är intressant, då detta är ett av få pollendiagram från höglandet som speglar utvecklingen i en dalgång. Tydligen har jordbruket och bebyggelsen här påverkats mindre av nedgångsperioder och befolkningsfluktuationer än omgivande marginalområden. Det stärker bilden av dalgången som en centralbygd.

\section{Agrarhistorisk analys}

Medeltidens bebyggelse och jordbruk har varit föremål för en tämligen intensiv forskning inom de historiskt baserade vetenskaperna. Vid sidan av byar med självständiga familje- 


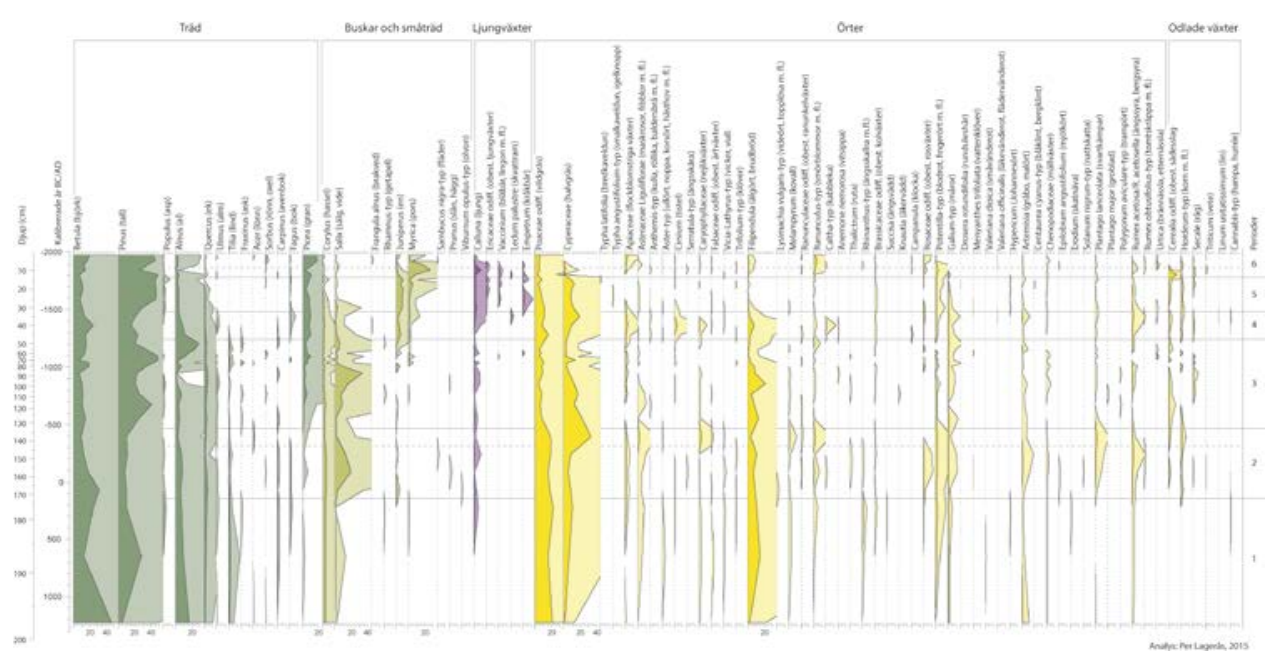

Figur 5. Pollendiagram över samtliga identifierade pollentaxa från analysen av borrkärna från Bredestad. Diagrammet är plottat mot en linjär tidsskala som baseras på sex C14dateringar (Lagerås 2016). De kraftigt färgade kurvorna visar procent av pollensumman (avläses påx-axlarna längst ner) medan de ljust färgade kurvorna visar samma värden multiplicerade med tio. Illustration: Per Lagerås, Arkeologerna, Statens historiska museer.

jordbruk (nedan benämnda bondgårdar) har alltmer uppmärksammats att det också funnits ett tämligen omfattande system med huvudgårdar och underlydande torp och landbogårdar. Dessa godskomplex var fullt utvecklade på 1200-talet, men en viss avveckling tycks ha inletts redan på 1300-talet. Avvecklingen påskyndades av den folkminskning och arbetskraftsbrist som följde under senmedeltiden i digerdödens och efterföljande pestepidemiers spår. Vid medeltidens slut dominerade familjejordbruken stort; huvudgårdar var då relativt sällsynta (Rahmqvist 1996; Tollin 1999; Hansson 2001; Berg 2003a; Ericsson 2012).

Den medeltida bebyggelsestrukturen var med andra ord varierad och genomgick ett antal genomgripande förändringar, orsakade företrädesvis av att nya produktionsformer infördes. Lite förenklat kan man för Sveriges gamla kulturbygder, det vill säga sådana med förhistoriskt ursprung, tala om tre produktionsformer, nämligen (1) storgårdsdrift, (2) huvudgårdsdrift och (3) landbodrift. Dessa sätt att organisera lantbruket på har avlöst men också överlappat varandra under loppet av medeltiden, men de har alla varit dominerande under var sin period (Ericsson 2012:40). Medan huvudgårdsdriften och landbodriften är tämligen väldokumenterade i de historiska källorna (Myrdal och Morell 2011:89) är storgårdsdriften mer hypotetisk på grund av ett knapphändigt källmaterial, såväl skriftligt som arkeologiskt. Trots detta har storgårdsdriften närmast tagits för given, särskilt inom kulturgeografisk forskning, och speciellt vad Småland och Östergötland beträffar (Tollin 1999; Berg 2003a, 2003b).

Kortfattat kan utvecklingen beskrivas som följer: Det första steget har rötter i vikingatiden och kännetecknas av att arbetet utfördes av på storgårdar inhysta trälar och legohjon. Under det andra steget frigavs trälarna för att ikläda sig nya roller inom godsets ramar, men 
först under det tredje steget blev familjejordbruket dominerande. Det andra steget tillhör högmedeltiden (cirka 1200-1350) och kännetecknas av lokala godskomplex bestående av en huvudgård med dels underliggande torp, vars brukare hade stor arbetsplikt, dels driftsmässigt självständiga landbogårdar, vars brukare gjorde få eller inga dagsverken på huvudgården. I stället erlade landborna en fixerad avrad till jordägaren i utbyte mot brukningsrätten. Parallellt med att träldomen minskade i betydelse och slutligen försvann har jord successivt avskilts från huvudgårdarna och fördelats på landbor. Systemet var med andra ord redan i upplösning när vi först kan fånga dess gestalt i medeltidsbreven och andra skriftliga källor. Efter digerdöden avvecklades nästan helt huvudgårdsdriften. I princip levde den endast kvar på adelns sätesgårdar och kyrkans avelsgårdar (Ericsson 2012).

En central frågeställning, som kopplas till frågan om ägande och elit, är om det finns en kontinuitet mellan vikingatidens stormannaklass och den tidigmedeltida aristokratin, vilken övergår i det världsliga frälset under andra hälften av 1200-talet (Poulsen och Sindbæk 2011). De personer som omnämnas på vikingatidens runstenar i Sverige kan emellertid inte i något fall visas vara anfäder till de stormän som omtalas i brev och andra skriftliga källor från äldre medeltid. Detta betyder inte att släktskap skulle saknas, men saken låter sig inte beläggas i källorna. En mer framkomlig väg är att istället undersöka på vilket sätt en vikingatida storgård har kontinuitet som sådan in i medeltiden och tillsvidare lämna den personhistoriska frågan åt sidan.

Den undersökta vikingatida storgården ligger som nämnts på ägor tillhörande gården Bona i Bredestads socken. Bona gränsar i väster till den lilla byn Bredestad och i öster till gården Kristineberg (förr Munkagård). Som framgår nedan har dessa bosättningar ett gemensamt ursprung. Under äldre medeltid har de nämligen utgjort en by med gles och utspridd bebyggelse inom gränserna för ett samlat ägoområde, som av allt att döma hetat Bredestad. Anmärkningsvärt är att det i denna by fanns två huvudgårdar som båda var centra i var sitt godskomplex. Detta ursprungliga Bredestad - varav den lilla byn Bredestad är en rest - har omfattat södra delen av Bredestadsdalen och är det område som står i fokus i följande agrarhistoriska analys av den medeltida bebyggelsestrukturen (figur 6).

Flera saker talar för att det under medeltiden har funnits ett geografiskt samlat godskomplex i Bredestad med centrum i Bona. Detta godskomplex har upplösts under senmedeltiden i brukningsmässigt självständiga bondgårdar. Den första saken som drar till sig vår uppmärksamhet är ortnamnet Bona, som är en sidoform till Bo, vilket betecknar en huvudgård i ett godskomplex (Rahmqvist 1994:109-110; Wahlberg 2003:39). Bo eller Bosgård är en inhemsk motsvarighet till medeltidsbrevens latinska beteckningar curia och mansio, vilka avser en huvudgård när de i brevens pertinensformler förekommer tillsamman med underliggande torp (cum coloniis) (Rahmqvist 1996:8-10).

Bredestads kyrka ligger som sagt i Bona och är en romansk stenbyggnad. Sådana började uppföras under 1100-talet på initiativ av kungar, biskopar eller lokalt förankrade stormän och förekom framför allt på huvudgårdar. Från att från början ha varit privata gårdskyrkor inlemmades de i stiftets organisation av sockenkyrkor med början av sent 1100-tal eller tidigt 1200-tal. Av allt att döma har Bredestds kyrka ett sådant ursprung och vi ser här ett tydligt samband mellan en medeltida huvudgård (Bona) och en romansk stenkyrka. Mönstret är sedan tidigare känt i Skandinavien (Bonnier 1996; Hedvall 2009; Tollin 2012).

Det är därför inte oviktigt att Bredestads socken under medeltiden ingick i det mäktiga Linköpings stift (Schück 1959). 


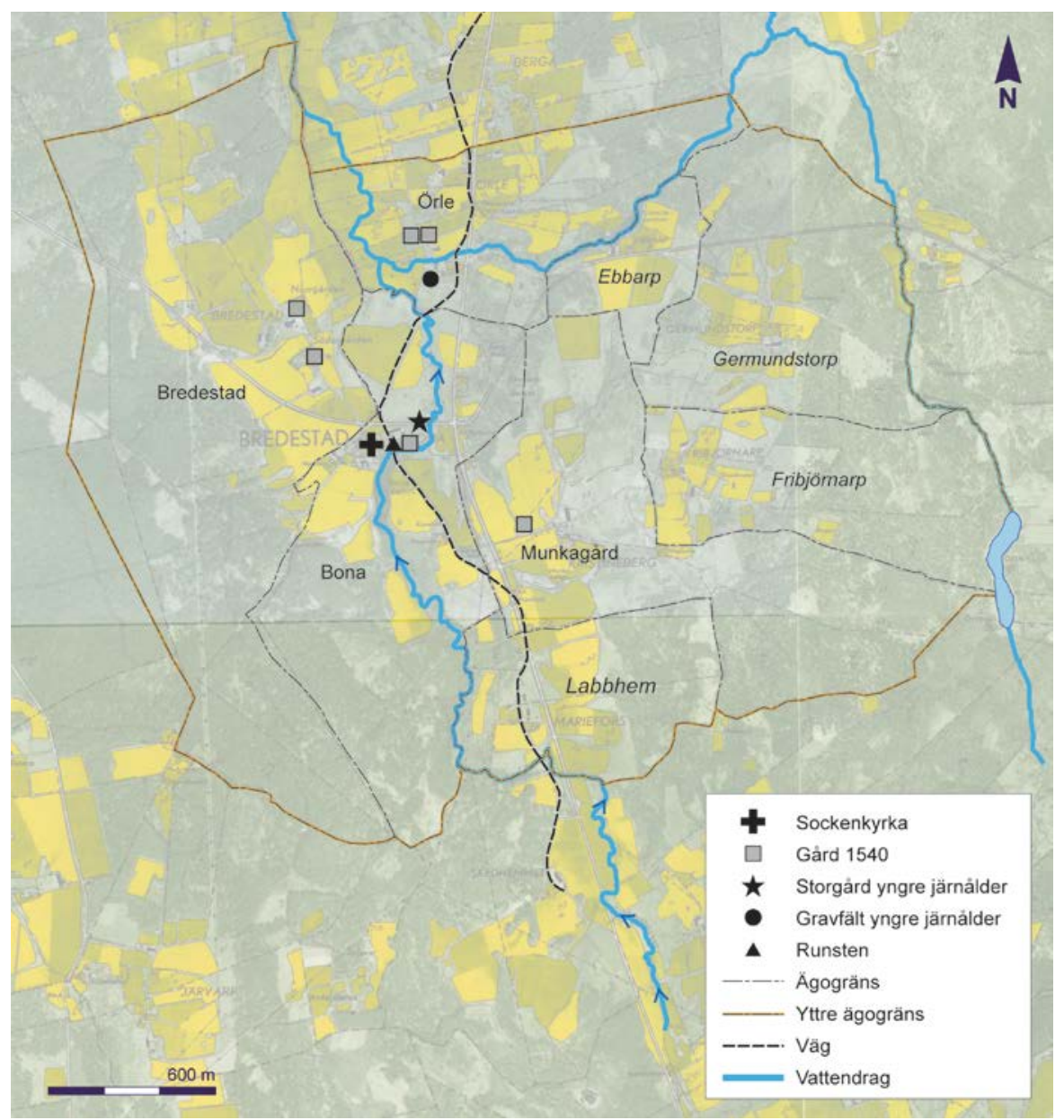

Figur 6. Under perioden 1200-1350 e.Kr. var Bredestad en gles by med två huvudgårdar, Bona och Munkagård. Dessutom ingick $i$ byns vidsträckta ägoområde de senare avsöndrade bondgårdarna i den lilla byn Bredestad liksom torpen Fribjörnarp, Germundstorp, Labbhem och Ebbarp. Troligen har också Örle ingått $i$ detta ägoområde och på vars marker det finns en stor förkristen begravningsplats. Lägg märke till att Bredestads sockenkyrka från 1100-talet ligger $i$ Bona, likaså den undersökta storgården från yngre vendel-och vikingatid. Här finns också en runsten från 1000-talet. Bona torde därför vara den äldsta och mest betydelsefulla av de båda huvudgårdarna, som var centra $i$ var sitt godskomplex. Bebyggelsen på kartan avser antalet gårdar i de äldsta jordeböckerna från 1539/42. Avgärdatorpen blev ödesmål under den senmedeltida agrarkrisen och var fortfarande öde när de första jordeböckerna upprättades. Ägogränserna är från lantmäterikartor från 1700-talet och första hälften av 1800-talet. Landsvägen finns utsatt på en karta från mitten av 1600-talet, men torde vara från medeltiden eller ännu äldre, vilket den vikingatida runstenen talar för. Skala 1:25 000. Kartan bygger på information i lantmäteriakter som specificeras i litteraturlistan LSA (2018) samt RAK (2018). Illustration: Alf Ericsson, Arkeologerna, Statens historiska museer. 
Gårdsnamnet Bona kan först beläggas i början av 1500-talet (SmH 2018:1539:9, 1542:6). $B o$ var från början en administrativ beteckning på en huvudgård i ett godskomplex och inte ett regelrätt bebyggelsenamn. Godskomplexet måste därför ha hetat Bredestad. För denna slutsats talar också förhållandet att Bredestads kyrka ligger på Bonas mark. Den i 1500-talets jordeböcker omtalade lilla byn Bredestad med sina två bondgårdar (SmH 2018:1539:9, 1542:6) torde därför vara en rest av ett godskomplex där Bona var huvudgård.

Anmärkningsvärt är att Bo/Bona inte var den enda huvudgården i Bredestad under äldre medeltid. Kristineberg var nämligen också en huvudgård. Denna fastighet benämndes fortfarande på 1600-talet Munkagård. Namnet kommer av att egendomen ägdes av Alvastra kloster, till vilket den skänktes av riddaren Holmger Ulfsson d.ä. 1307 (SDHK 2018:2169), tillhörig frälseätten Ama, som härstammar från den år 1210 i slaget vid Gestilren stupade Folke jarl. Vi lägger märke till att egendomen i gåvobrevet omtalas som Holmgers huvudgård Bredestad $\mathrm{i}$ Vedbo härad (Curiam meam bredhoestadher in vidbo situatam) och att till denna ligger vattenkvarnar, torp, åkrar, ängar, betesmarker och fisken (cum molendinis coloniis agris pratis pascuis et piscariis). Att det har funnits byar med flera huvudgårdar har tidigare uppmärksammats inom den agrarhistoriska forskningen (Ericsson 2012:102, 162). Det är viktigt att skilja sådana enheter från byar med ordinära familjejordbruk. Efter det att Alvastra kloster tog över egendomen har munkarna avvecklat huvudgårdsdriften och i stället infört landbodrift, vilket var den normala utvecklingen på 1300-talet.

De underliggande torpen namnges inte i gåvobrevet, men ett av dem bör ha varit Målen, som också ägdes av Alvastra kloster (SmH 2018:1539:9, 1540:6). Målen ligger ett stycke öster om Munkagård och torde vara upptagen på Vedbos häradsallmänning. Av ägoområdenas/fastighetsgränsernas geometri framgår emellertid att Fribjörnarp, Germundstorp, Labbhem (nu Mariefors) och Ebbarp också har ingått bland de underliggande torpen. Dessa enheter saknade bebyggelse när de första jordeböckerna upprättades 1539/42. Studerar man ägofigurerna är det tydligt att torpen är avsöndrade från Munkagård (jfr. figur 6). Nämnda torp synes ha tagits ur bruk under senmedeltiden och var fortfarande inte bebyggda i mitten av 1500-talet. Det är känt att Vedbo härad drabbades hårt av den senmedeltida agrarkrisen (Bååth 1983). I anslutning till samtliga torp finns omfattande områden med fossil åkermark, som inte var odlade på de historiska kartorna. Därför torde de vara från medeltiden eller tidigare, vilket styrker antagandet att Fribjörnarp och de andra torpen fanns redan på medeltiden.

Slutsatsen blir att Bredestad under äldre medeltid (före 1350) utgjorde en by med en glest grupperad bebyggelse inom ett betydande ägoområde (jfr. figur 6). Förutom bondgårdar har också huvudgårdarna Bona och Munkagård ingått. Dessa huvudgårdar var centra i var sitt godskomplex. Från Munkagård har flera avgärdatorp avsöndrats. Likaså torde gårdarna $\mathrm{i}$ den nutida lilla byn Bredestad vara avstyckningar, närmare bestämt från en vikingatida storgård. Högst sannolikt har också Örle med sitt stora yngre järnåldersgravfält ingått i det ursprungliga Bredestad. Ortnamnet Bredestad blir därmed mer begripligt. Det ingående adjektivet bred synes åsyfta ett ovanligt brett och omfattande ägoområde med en flerkärnig bebyggelse. I Bona har alltsedan yngre järnålder funnits en storgård och från och med 1100talet en stenkyrka, senare upphöjd till sockenkyrka. När den andra huvudgården (senmedeltidens Munkagård) tillkom är oklart, men den fanns senast på 1200-talet. 


\section{En storgård från yngre järnålder}

Vid mitten av vendeltid, kring 650 e.Kr, etablerades en storgård vid Bona, 100 m öster om Bredestads kyrka, på en plats där det tidigare inte verkar ha funnits någon bebyggelse. Däremot fanns flera härdar från äldre järnålder, vilka kan ha samband med aktiviteter i Vibäckabäckens närhet. Äldre järnålderns landskap (jfr. figur 4) hade karaktäriserats av att såväl dalgången som omgivande höjdstråk utnyttjats för bete och odling. På höjdstråken finns röjningsröseområden som torde representera en bebyggelse av spridda gårdar från särskilt romersk järnålder. Dessa höglänta områden övergavs under folkvandringstid. Den vendeltida bebyggelseetableringen skedde således efter en period av stark tillbakagång, ofta benämnd den folkvandringstida krisen (Pedersen och Widgren 1998:309-311; jfr. Wickham 2005).

\section{Platsen och landskapet}

Placeringen av den nya gården i dalgångens botten är del av ett större mönster i denna del av Småland - under yngre järnålder koncentrerades nämligen såväl bebyggelse, gravar som markanvändning till dalgångarna (Jansson och Kristensson 2004:48). Pollendiagrammet från Bredestad visar att betesindikationerna minskade och de tidigare intensivt använda röjningsröseområdena har växt igen med tallskog. Såväl odling som bete och slåtter har då koncentrerats till dalgången, där mera lättbrukade och bördigare marker fanns. Däremot har odlingen av korn fortsatt utan avbrott på de bördiga jordarna i dalgångens botten och rågodlingen ökade från cirka 700 e.Kr. Under 800-talet har våtmarkerna upprepade gånger röjts för slåtter, något som möjligen kan kopplas till en utökad vinterstallning av husdjuren och en tydligare inriktning mot mjölkhushållning.

Yngre järnålderns gårdsbebyggelse var placerad på ömse sidor av Vibäckabäcken, det mindre vattendrag som rinner genom dalen. På båda sidor om bäckfåran finns breda sanka partier - trots ett avstånd på $100 \mathrm{~m}$ har byggnaderna tolkats som delar av samma gård. Den undersökta bebyggelsen låg i anslutning till den historiska gårdstomten i Bona, dock inte på själva tomten (jfr. figur 3). Det nya bebyggelseläget har haft ett utmärkt kommunikativt läge. Dalen och dess fortsättning mot sjösystem och åar norrut leder vidare till slättbygderna i Östergötland. Mot väster har man i passet mellan höjderna kunnat ta sig till Jönköpingstrakten. Den vendel- och vikingatida storgårdens huvudbyggnad var placerad med riktning öst-väst, medan övrig bebyggelse var orienterad nord-syd. Huvudbyggnaden fick härmed en extra stor exponering mot den gamla Kungsvägen. Oavsett om en resande närmade sig gården på landsvägen från norr eller från söder, så syntes gården och framför allt dess huvudbyggnad på långt håll, där den låg mitt $\mathrm{i}$ dalen. Det finns all anledning att förmoda att detta spelat in när byggnaden uppförts, något som talar för att vägen funnits redan då.

Cirka 150 m öster om bäcken fanns två stensättningar, en större och en mindre (Sjölin 2016). Den större, som byggts under romersk järnålder, låg i manifest läge, på en höjd med tydlig exponering mot dalgången. Bakom denna fanns en mindre och inte så välbyggd stensättning, där en ung vuxen individ gravlagts vid mitten av vendeltid. Placeringen av den yngre graven vittnar om en önskan att peka på förbindelser bakåt i tid, antingen faktiska eller önskade. Kanske har syftet varit att demonstrera eller hävda sitt släktskap med tidigare markrättighetsinnehavare i samband med att en ny storgård etableras i området (jfr. Hållans Stenholm 2012). 


\section{Gårdstomten}

Storgården från yngre järnålder var placerad på ömse sidor av ett mindre vattendrag (figur 7). Huvudbyggnaden låg väster om bäcken på ett avstånd av 25 m från den historiska gårdstomten, och var något högre belägen än övriga byggnader på gården. Denna bedöms ha haft en offentlig funktion men också varit bostad för gårdens ägare. Öster om bäcken, och $100 \mathrm{~m}$ öster om den historiska gårdstomten, låg de delar av gården som mera tydligt kan kopplas till ekonomi, matlagning och hantverk, men åtminstone ett av husen har fungerat som bostad. Vi bedömer, på grundval av bebyggelsens karaktär, datering och fyndmaterial att det rör sig om en gård, inte två. Den förhistoriska gårdstomten har således bestått av minst två separata delar, åtskilda av en bäck och kring denna ett sankt parti. I den västra delen bygger uppskattningen av gårdstomtens storlek främst på topografiska hänsyn medan den östra delens storlek får anses mera säker och bygger på sökschakt. Den västra delen omfattade uppskattningsvis minst $2900 \mathrm{~m}^{2}$ men kan ha varit hela $6000 \mathrm{~m}^{2}$ och sträckt sig ända fram till vägen. Den östra delen uppgick till cirka $2800 \mathrm{~m}^{2}$. På den historiska gårdstomten har inga arkeologiska undersökningar genomförts och vi känner därför inte till om även detta område ingått i yngre järnålderns gårdstomt. Vi antar dock att så varit fallet. Den

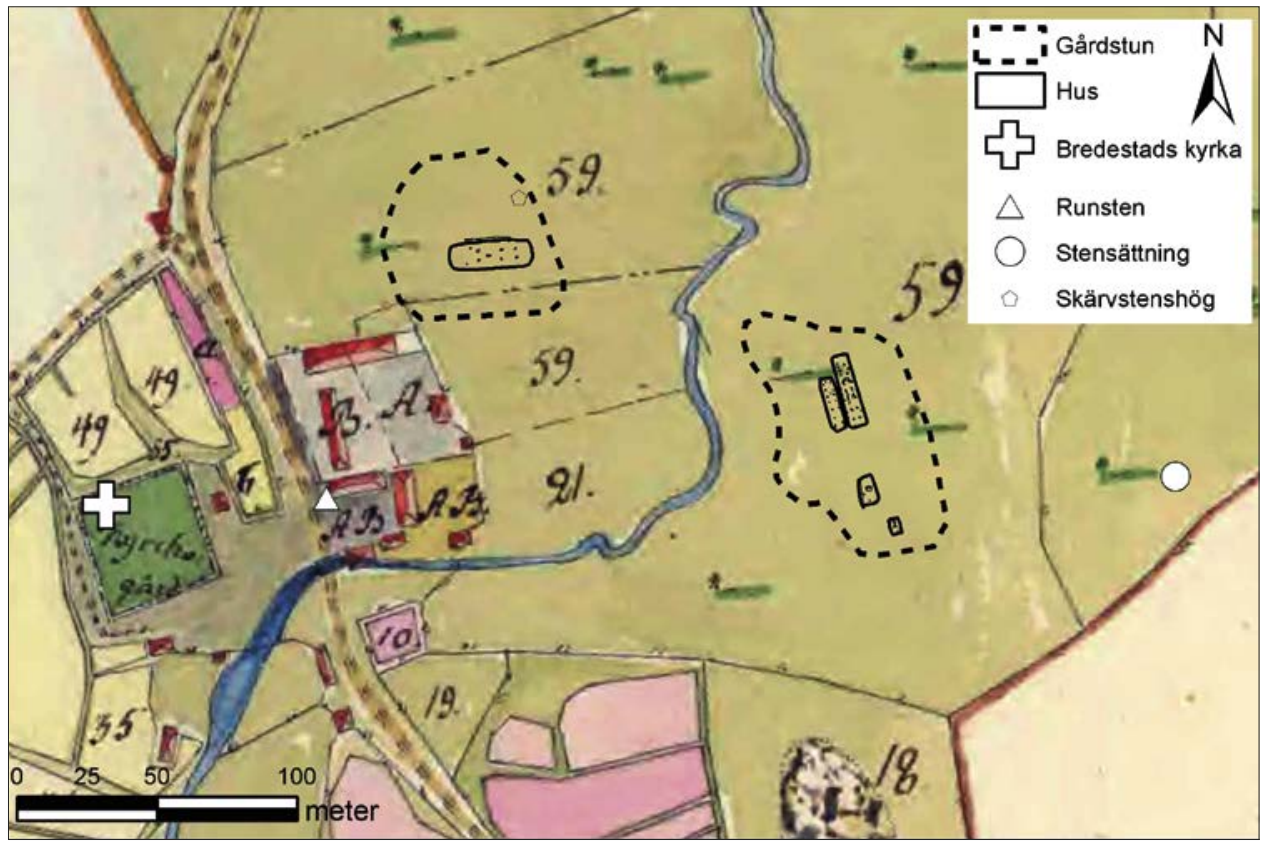

Figur 7. Läget för den tudelade gårdstomten med byggnader, åren 650-1000 e.Kr.

Utbredningen av tomten öster om bäcken är väl avgränsad med sökschakt medan utbredningen av tomten väster om bäcken framför allt bygger på topografi. Den skulle dock kunna sträcka sig västerut ända till vägen och också omfatta den del som är bebyggd i historisk tid. Skala 1:3000. Efter Sjölin 2016 och storskifteskarta över Bona i Bredestad socken 1811 (LSA 2018:Akt E18-5:1). Illustration: Marita Sjölin, Arkeologerna, Statens historiska museer. 
förhistoriska tomten måste med andra ord ha bestått av flera delar och de bebyggda partierna kan ha uppgått till cirka $13000 \mathrm{~m}^{2}$.

\section{Fynden}

För att skapa en ram för kommande kronologiska resonemang presenteras fyndmaterialet före byggnadslämningarna. Fyndmaterialet från Bona var begränsat, ett förhållande som i sig inte är ovanligt när det gäller undersökningar av yngre järnålderns bosättningar i Småland (Nylén och Söderberg 2009). Fynden ger ändå viktig information om gårdens sociala status och bidrar till tolkningen av gårdstomtens funktionsindelning. Vidare kompletterar fynden de dateringar som gjorts med hjälp av C14-analys.

I området väster om bäcken påträffades de flesta fynden i ett skärvstenslager som anbringats på huslämningarna i samband med att huvudbyggnaden tagits ur bruk. Lagret var $120 \mathrm{~m}^{2}$ stort och $0,1-0,3 \mathrm{~m}$ tjockt. Endast $22 \mathrm{~m}^{2}$ undersöktes, något som delvis förklarar den sparsamma fyndmängden. Materialet $\mathrm{i}$ lagret bedöms ha tagits från en plats nära huset - tio meter norr om huset finns till exempel en skärvstenshög, något som visar att man samlade in denna typ av material. Fynden kan därmed härröra från huvudbyggnadens hela användningstid. Öster om bäcken tillvaratogs metallfynden främst i matjordslagret i samband med metalldetektering över hela ytan.

Fynden från Bona kan delas upp i tre grupper. Huvuddelen utgörs av vardagliga föremål som har samband med drift och underhåll av storgården. Det finns några enstaka högklassiga föremål som kan tolkas som prestigefyllda och peka mot en elitär miljö. Dessutom finns föremål förbundna med olika typer av specialiserat hantverk, även detta har en koppling till elitära miljöer. De vardagliga fynden förekommer i ungefär likvärdig omfattning både vid huvudbyggnaden väster om bäcken och vid ekonomibyggnaderna öster om bäcken, medan prestigefynden och fynd som visar på specialiserat hantverk främst förekommer vid huvudbyggnaden (tabell 2).

Keramiken fanns endast väster om bäcken, medan vävtyngderna (med plan-konvext tvärsnitt) var ungefär jämnt fördelade på båda sidor bäcken. Keramiken kan dateras till yngre järnålder, men kan inte närmare periodbestämmas (Karin Lindeblad, Arkeologerna, Statens historiska museer, personlig kommunikation 3. mars 2017). En skärva är dekorerad med dubbla streck och kan möjligen vara östersjökeramik, en typ som brukar dateras till 1000-1250 i regionen (Roslund 2001). Vidare fanns några malstensunderliggare till gnidkvarnar i området öster om bäcken. Järnslagg och teknisk keramik (ugnsväggar) förekommer på båda sidor av bäcken, men är något vanligare på östra sidan. Huvuddelen av slaggen är produktionsslagg från blästugnar för järnframställning, men det finns enstaka bitar smidesslagg. Intressant nog förekommer båda typerna av slagg och stora stycken teknisk keramik som skoning till stolphål i det yngre av de båda treskeppiga husen öster om bäcken. Det visar att järn framställts och smitts på plats redan under vendeltid. Inga lämningar som kunnat tolkas som en smedja har framkommit men, förutom smidesslaggen, talar ett ämnesjärn och en smälta av järn för att smide förekommit på gården. En oanvänd hästbrodd pekar tydligt på ett mer vardagligt smide. Broddar uppträder först under senare delen av 500-talet och var vanliga under vikingatid och tidig medeltid (Sundkvist 2001:72; Beronius Jörpeland och Seiler 2011:160). I Bona fanns ett håljärn (mejsel), vilket indikerar trähantverk. En visselpipa av trä hittades nära bäckens östra strand. 
Tabell 2. Fyndsammanställning över registrerade fynd från undersökningar $i$ Bona med sakord, material och antal fyndposter fördelade efter vilken sida av bäcken de hittats (efter Jansson och Kristensson 2004; Jansson och Rödjer 2014; Sjölin 2016). I sammanställningen har fyndposter som sintrad sand, djurben, två avslag av flinta och ett fragment av en slipad stenyxa etcetera tagits bort. Fynden har också delvis omtolkats och utifrån detta har antalet fyndposter beräknats.

\begin{tabular}{|c|c|c|c|}
\hline Sakord; del & Material & Väster om bäcken & Öster om bäcken \\
\hline Armborstpil & Järn & & 2 \\
\hline Avslag & Flinta & & 2 \\
\hline Brodd & Järn & 1 & 1 \\
\hline Bränd lera & Bränd lera & 21 & 8 \\
\hline Degel? & Bränd lera & 1 & \\
\hline Håljärn & Järn & & 1 \\
\hline Hästsko & Järn & & 1 \\
\hline Hästskosöm & Järn & 1 & 1 \\
\hline Klipp & Brons & 1 & \\
\hline Kniv & Järn & 2 & 1 \\
\hline Kniv eller pilspets & Järn & & 1 \\
\hline Knivämne? & Järn & 1 & \\
\hline Kula & Bly & & 1 \\
\hline Kärl; fragment & Keramik & 12 & \\
\hline Lerklining & Bränd lera & 3 & 6 \\
\hline Malsten; underliggare & Bergart & & 3 \\
\hline Nyckel; klo- & Järn & 1 & \\
\hline Pärla & Glas & 5 & \\
\hline Rembleck & Brons, guld & 1 & \\
\hline Ringnål; torne & Brons, guld & 1 & \\
\hline Ringnål; torne & Järn & & 1 \\
\hline Slagg & Järn & 9 & 19 \\
\hline Smälta & Brons & & 1 \\
\hline Smälta & Järn & & 1 \\
\hline Spill & Järn & 1 & \\
\hline Teknisk keramik (ugnsväggar) & Bränd lera & 9 & 14 \\
\hline Visselpipa & Trä & & 1 \\
\hline Vävtyngd & Bränd lera & 7 & 6 \\
\hline Yxa; fragment & Bergart & & 1 \\
\hline Ämnesjärn? & Järn & 1 & \\
\hline Totalt: & & 78 & 72 \\
\hline
\end{tabular}


De föremål som kan peka mot en mer elitär miljö var få. Här fanns ett rembleck samt två tornar tillhöriga stora ringnålar. Remblecket kan beskrivas som en dekorerad platta som suttit på en läderrem eller ett bälte. Blecket är rektangulärt, $25 \times 10 \mathrm{~mm}$ stort och $1 \mathrm{~mm}$ tjockt. Framsidan är försedd med ett smårutigt rombmönster och förgyllt. Rembleck förekommer under vikingatid och tidig medeltid, men dekoren är ovanlig på metallföremål. Liknande dekor finns på en remlöpare av silver från en grav på Lovö utanför Stockholm (Petré 1984:395). De två tornarna till ringnålar är av brons respektive järn och 7 respektive $10 \mathrm{~cm}$ långa. Den förstnämnda är punktornerad och den andra ornerad med tvärställda streck och kryss. Ringnålar förekommer främst under vikingatid och förknippas vanligen med mansdräkten (Hårdh 1999, 2003; Beronius Jörpeland och Seiler 2011:118). Bland fynden finns även en nyckel, troligen en del av en klonyckel. Klonycklar förekommer främst under vikingatid men även under medeltid (Cinthio 1998; Sköld 2012). Järntornen tillvaratogs $\mathrm{i}$ området öster om bäcken, övriga föremål med elitär anstrykning fanns vid huvudbyggnaden väster om bäcken.

Flera föremål pekar mot olika typer av specialiserat hantverk. Små fina knivar inklusive ett knivämne representerar ett avancerat klensmide och visar att en högt specialiserad smed funnits på platsen (åtminstone periodvis). Knivar med blad under $8 \mathrm{~cm}$ har använts i arbeten som krävt stor precision som exempelvis träsnideri, läderarbete och textilarbete (Häggström 2005:267-268). Fynd av bronsklipp, gjutformsfragment, en möjlig degel och en smälta av brons visar att även bronsgjutning har förekommit. Fem pärlor av glas, tre blå, en turkos och en gulgrön, kan möjligen tala för att pärltillverkning har förekommit i Bona. Några av dem är nämligen fragmenterade och smälta. Pärlorna är funna väster om bäcken. I regionen finns endast ett fåtal kända platser där pärltillverkning förekommit. En av dessa är hantverks- och handelsplatsen från yngre järnålder i Herrebro i norra Östergötland, där pärltillverkning förekom tillsammans med en rad andra specialisthantverk (Lindeblad 2008). Fynden som indikerar specialiserat hantverk fanns på båda sidor av bäcken, men med tyngdpunkt på den västra sidan.

Öster om bäcken fanns två armborstpilar. Det finns i nuläget ingen övergripande kronologisk bearbetning av det svenska beståndet med armborstpilspetsar. Möjligen kan man ana att den kortare och holkförsedda typen som finns i Bona börjar uppträda under 1200-talet (Beronius Jörpeland och Seiler 2011:168). Armborstpilarna kan peka mot att området öster om bäcken använts för gårdsnära aktiviteter även efter att byggnaderna i området försvunnit.

Genomgången ovan visar att fynden vid Bona till övervägande del kan kopplas till drift och underhåll av en gård, liksom till mat, matlagning och husbehovsslöjd för gårdens behov. Det finns dock enstaka föremål som indikerar ett annat, mera elitärt sammanhang. Dessa föremål, ett förgyllt remändebeslag och två stora ringnålar har tillhört dräkten och att bära dem har varit ett sätt för specifika individer att demonstrera sin status (jfr. Reiersen 2017). En klonyckel kan också möjligen tillhöra denna grupp av föremål. Dessutom finns indikationer på några specialiserade hantverk som inte direkt har samband med den vardagliga gårdsdriften. Det är klensmide, bronsgjutning och eventuellt pärltillverkning, som även dessa kan sägas indikera en mer elitär miljö. Här kan noteras att det i elitära miljöer från yngre romersk järnålder och folkvandringstid i Väst-Norge sällan förekommer verkstäder med produktion av elitföremål (Reiersen 2017). Även få indikationer kan alltså vara betydelsebärande. 
Föremål som pekar mot en elitär miljö var få till antalet. De vittnar inte om den vidlyftiga lyxkonsumtion som förekommit vid storgårdar som Uppåkra (Hårdh 1999, 2003) och Järrestad (Söderberg 2003), båda i Skåne. Istället finns det vissa likheter med andra elitära miljöer, som Huseby och Hjärup (Nylén och Söderberg 2009; Schmidt Sabo m.fl. 2011), som utan tvekan kan klassificeras som storgårdar, men inte för den allra högsta sociala eliten i samhället. Det förgyllda remblecket och ringnålarna kan tolkas som prestigeföremål som väl passar för en lokal magnat och hans familj. Förekomsten av flera specialiserade hantverk stärker denna bild. Klensmide, bronsgjutning och framför allt pärltillverkning är hantverk som sällan förekommer på yngre järnålderns gårdar. Fyndmaterialet visar att de två områdena på vardera sidan av bäcken haft olika funktion. Väster om bäcken fanns merparten av prestigeföremålen jämte keramiken och det specialiserade hantverk var något mer företrätt här. Öster om bäcken fanns motsvarande övervikt för vardagliga hantverk och malstenar. Vävtyngder fanns på båda sidor, men de av knubbig typ fanns främst på den västra. Alla fynd väster om bäcken kan dateras till yngre järnålder, i några fall tydligt till vikingatid. Även öster om bäcken dominerar fynd som kan dateras till yngre järnålder och särskilt då till vikingatid, men här finns även ett yngre inslag i form av medeltida armborstpilar och en hästsko.

\section{Huvudbyggnaden - gårdstomten väster om bäcken}

Huvudbyggnaden har tillika varit gårdens största byggnad, med svagt konvexa väggar (Jansson och Kristensson 2004; Sjölin 2016). Ursprungligen har den varit knappt 30 m lång och $10 \mathrm{~m}$ bred (figur 8). Till ytan torde byggnaden ha varit cirka $270 \mathrm{~m}^{2}$. De sex takbärande stolparna har varit kraftiga - stolphålen hade en diameter av cirka $1 \mathrm{~m}$ - och fördelade sig så att ett större centralt rum åstadkoms där huset var som bredast. Mellanväggarna har varit placerade så att första och andra stolpparet från väster legat en bit i rummet. Rummet har sannolikt varit hela $14 \mathrm{~m}$ långt och därmed $140 \mathrm{~m}^{2}$. Den minsta tänkbara arealen för rummet är $80 \mathrm{~m}^{2}$. I dess absoluta mitt fanns en två meter lång, oval härd, kring denna fanns symmetrisk belägna stolphål antagligen från en konstruktion tillhörig härden. I rummet fanns ytterligare flera mindre, systematiskt arrangerade stolphål, vilka till exempel kan ha utgjort förankring för väggfasta bänkar (Streiffert 2005). I en grop nära en ingång till det centrala rummet hittades fragment av flera vävtyngder och keramik av typisk yngre järnålderstyp. Placeringen kan indikera att en stående vävstol haft sin plats strax i närheten (Nordström och Herschend 2003). I rummets nordöstra del har funnits en flack förrådsgrop med träklädd botten. Rummet tolkas som en representativ, mera offentlig del av byggnaden. Fyndmaterialet från byggnaden är inte karaktäristiskt för en hallbyggnad (Herschend 1993), varför vi antagit att byggnaden även fungerat som bostad för gårdens ägarfamilj. I husets västra del fanns ett mindre rum där takbärande stolpar saknats. Möjligen har istället väggarna här burit upp takets tyngd. Här fanns en mindre härd och ett par kokgropar. Kanske det rör sig om en mera privat avdelning i byggnaden, möjligen själva bostaden för ägarfamiljen? I husets östra del har också funnits ett mindre rum, vars närmare funktion inte kunnat avgöras. Det har funnits flera ingångar till huset - två identifierades på den norra långväggen och en på den södra. Dessutom fanns på norra väggen stolphål som tolkades som lämningar av ett ljusinsläpp - ett fönster (jfr. Ethelberg 2003:227). 


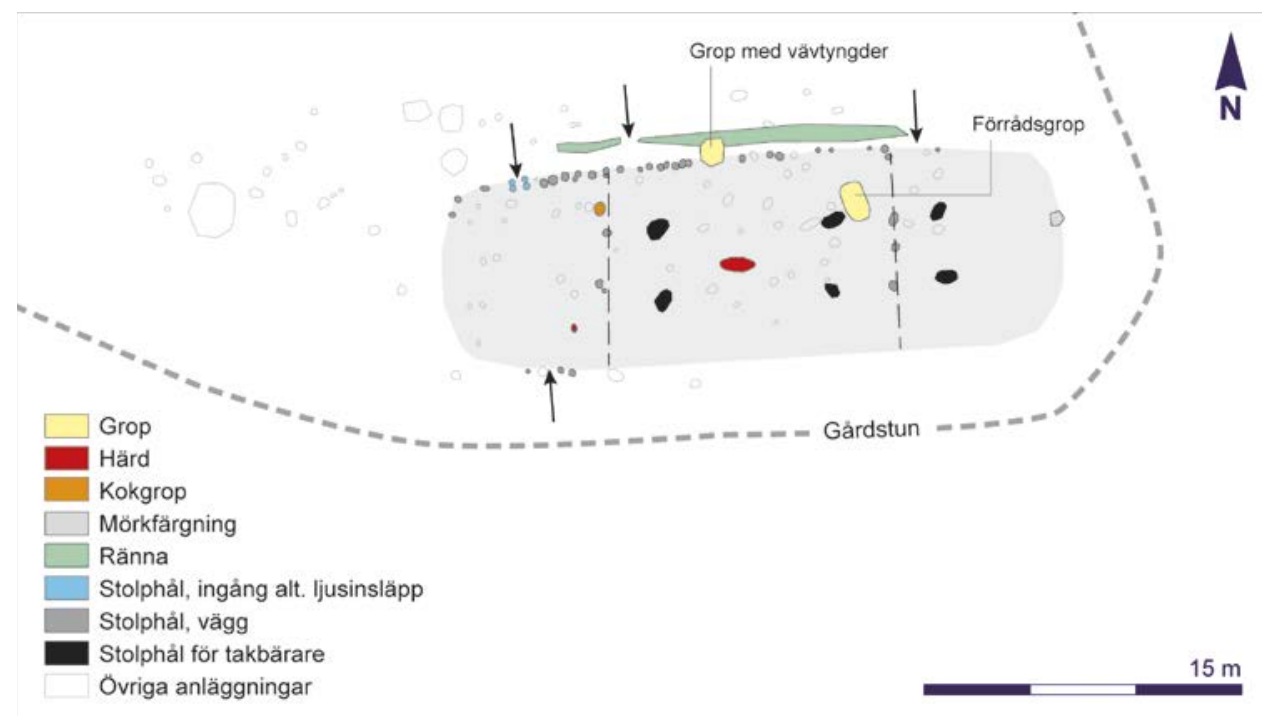

Figur 8. Tolkning av gårdens huvudbyggnad. Efter Jansson och Kristensson 2004; Sjölin 2016. Skala 1:400. Illustration: Marita Sjölin, Arkeologerna, Statens historiska museer.

C14-dateringarna från härdar och stolphål i byggnaden tyder på att den har haft en ansenlig livslängd (tabell 3). Fem dateringar ligger inom intervallet 650-1000 e.Kr. och fyndmaterialet placeras i ungefär samma tidsintervall (Jansson och Kristensson 2004). Vår bedömning av publicerade planer är att det rör sig om en byggnad som reparerats vid upprepade tillfällen. Av det arkeologiska materialet framgår tydligt att huvudbyggnaden övergavs under kontrollerade former troligen under 900-talets senare del eller början av 1000talet, något som understryks av fynden från området. Huset har rivits och platsen täckts över med ett flera decimeter tjockt lager av skärvsten, sannolikt som ett led i ritualer i förbindelse med övergivandet (Carlie 2004:193-194). Fenomenet är känt från andra platser i Sverige där yngre järnålderns kultbyggnader har övertäckts i samband med övergivandet (Lindeblad och Nielsen 1997; Bäck och Hållans Stenholm 2012). Likheterna kastar ytterligare ljus över funktion och symbolik förbunden med huvudbyggnaden vid Bona, den verkar också ha varit förbunden med en rituell aspekt. Från skärvstenslagret kommer de allra flesta föremålen från detta område, något som visar att skärvstenen bör komma från husets närhet. Kanske har här funnit en stenlagd gårdsplan eller liknande? En skärvstenshög finns ännu ett tiotal meter norr om huvudbyggnaden och visar att materialet här, liksom på många boplatser från äldre järnålder, samlades in för vidare användning (till exempel Petersson 2002). Även från norskt område finns exempel på att skärvsten, tolkat som avfall från ölbryggning, samlats i högar under perioden (Grønnesby och Heen-Pettersen 2015).

Sammanfattningsvis kan sägas att byggnadens manifesta placering i landskapet, dimensioner, utformning och långa användningstid talar för att den använts som huvudbyggnad i en storgård under vendel- och vikingatid. Byggnaden var ingen regelrätt hallbyggnad (jfr. Herschend 1993), däremot torde den ha uppförts för att ge en prestigefylld framtoning till 
Tabell 3. I tabellen visas först C14-dateringar i området väster om bäcken (RÄ̈ 78) och därefter i området öster om bäcken (RÄ̈ 183). Särskilt öster om bäcken visar C14dateringarna på aktivitet före yngre järnålder. Undersökningarna har dock visat att det då saknats bebyggelse i området. Dessa dateringar relaterar istället till aktiviteter av mera tillfällig art. Atmosfäriska data från Kueppers m.fl. (2004); OxCal v3.10 Bronk Ramsey (2005); cub r:5 sd:12 prob usp[chron].

\begin{tabular}{|c|c|c|c|c|c|}
\hline RAÄ & Lab nr. & Ålder BP & Kalib. 1 sigma & Kalib. 2 sigma & Daterat material \\
\hline 78 & Ua-20796 & $9100 \pm 65$ & 8430-8240 f.Kr. & $8530-8200$ f.Kr. & tall \\
\hline 78 & Ua-20789 & $1320 \pm 40$ & 660-770 e.Kr. & 650-780 e.Kr. & al \\
\hline 78 & Ua-20795 & $1265 \pm 45$ & 680-130 e.Kr. & 660-890 e.Kr. & al \\
\hline 78 & LuA-4892 & $1230 \pm 100$ & 642-995 e.Kr. & 683-887 e.Kr. & - \\
\hline 78 & LuA-4857 & $1205 \pm 100$ & 656-1014 e.Kr. & 690-942 e.Kr. & - \\
\hline 78 & Ua-20797 & $1180 \pm 45$ & 770-940 e.Kr. & 720-980 e.Kr. & salix \\
\hline 183 & Ua-51813 & $3268 \pm 192$ & 1900-1300 f.Kr. & 2100-1000 f.Kr. & vide/pil \\
\hline 183 & Ua-47800 & $1994 \pm 30$ & 40 f.Kr.-50 e.Kr. & 60 f.Kr. -80 e.Kr. & ek \\
\hline 183 & Ua-47797 & $1942 \pm 30$ & 20-115 e.Kr. & 20-130 e.Kr. & ek \\
\hline 183 & Ua-47798 & $1930 \pm 39$ & 25-125 e.Kr. & 40 f.Kr.-210 e.Kr. & ek \\
\hline 183 & Ua-47799 & $1924 \pm 31$ & 50-125 f.Kr. & 0-140 e.Kr. & björk \\
\hline 183 & Ua-31988 & $1861 \pm 30$ & 80-220 e.Kr. & 70-230 e.Kr. & björk \\
\hline 183 & Ua-31990 & $1271 \pm 30$ & 685-730 e.Kr. & 660-820 e.Kr. & tall \\
\hline 183 & Ua-47801 & $1264 \pm 30$ & 685-775 e.Kr & $660-860$ e.Kr. & björk \\
\hline 183 & Ua-51814 & $1235 \pm 29$ & 690-860 e.Kr. & $680-880$ e.Kr. & björk \\
\hline 183 & Ua-51815 & $1203 \pm 29$ & 775-870 e.Kr. & 710-900 e.Kr. & björk \\
\hline 183 & Ua-31991 & $1196 \pm 30$ & 775-875 e.Kr. & 710-940 e.Kr. & asp \\
\hline 183 & Ua-31992 & $1141 \pm 30$ & 875-975 e.Kr. & 780-990 e.Kr. & ek \\
\hline 183 & Ua-47796 & $1122 \pm 33$ & 890-975 e.Kr. & 810-1000 e.Kr. & ek \\
\hline 183 & Ua-31994 & $1040 \pm 35$ & 970-1025 e.Kr. & 890-1040 e.Kr. & björk \\
\hline 183 & Ua-31993 & $981 \pm 30$ & 1010-1150 e.Kr. & 990-1160 e.Kr. & björk \\
\hline
\end{tabular}

hela gårdsanläggningen, och den påminner i mycket om en hallbyggnad. En direkt parallell är huvudbyggnaden i storgården vid Hjärup, som givits en liknande tolkning (Schmidt Sabo m.fl. 2011).

\section{Gårdstomten öster om bäcken}

På en avsats strax öster om Vibäckabäcken fanns lämningar av två treskeppiga hus som avlöst varandra på platsen under vendel- och vikingatid, under den period då den betydligt mera långlivade huvudbyggnaden existerat väster om bäcken (Jansson och Rödjer 2014; Sjölin 2016). Vidare fanns här två ekonomibyggnader, den ena tolkas som ett brygghus (för ölbryggning) och den andra som en bakstuga med rester av en stor kupolugn. Här fanns också en blästerugn, använd för järnframställning. Till denna del av gårdstomten förefaller man ha lokaliserat aktiviteter som haft samband med jordbruket och djurhållningen, mat- 


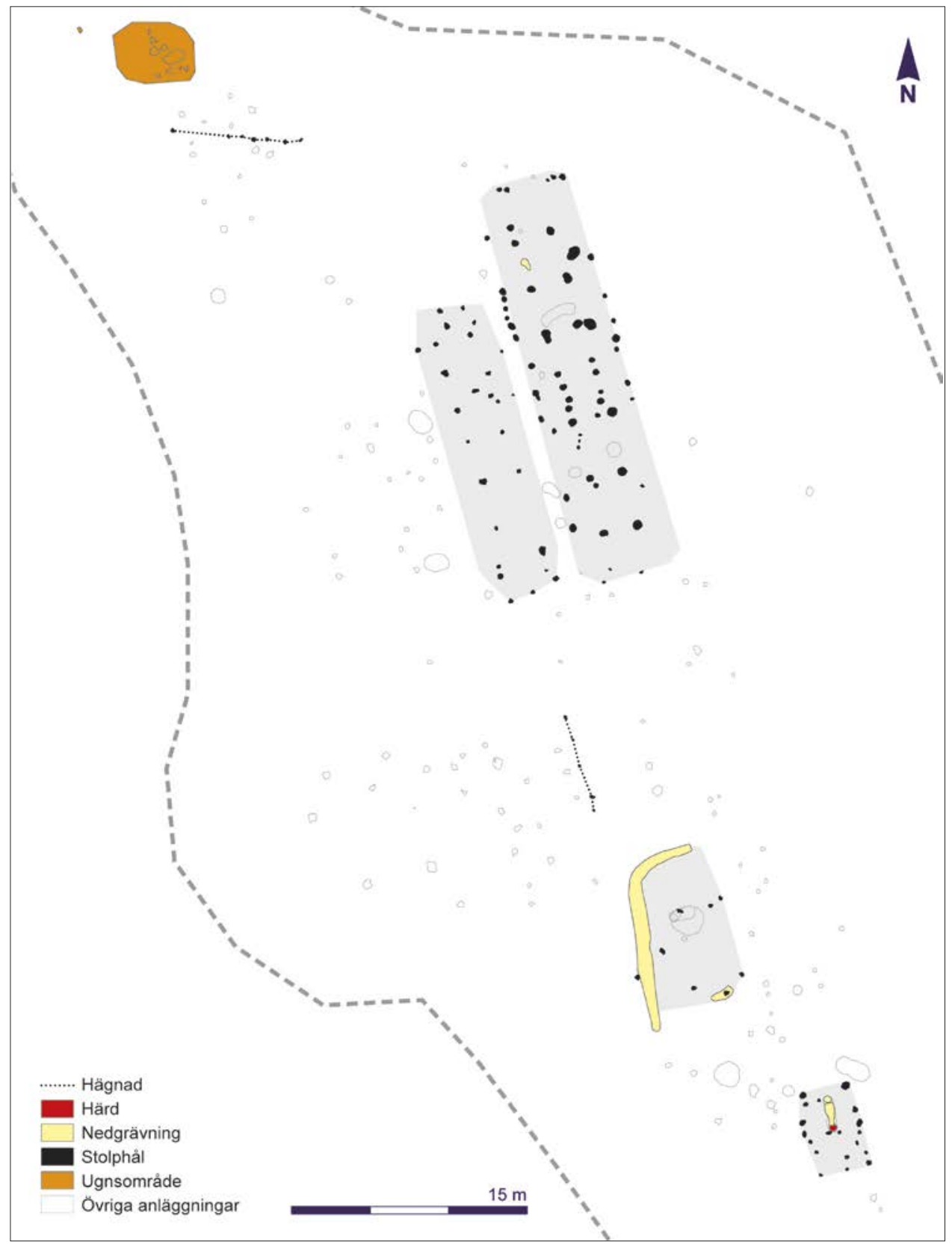

Figur 9. Tolkning av östra delen av tomten med byggnader. Under den äldsta fasen, 650-890 fanns endast det västra långhuset. Under den yngre fasen ersätts det första långhuset med ett nytt, betydligt större. Samtidigt tillkommer en bakstuga och längst i söder ett hus för ölbryggning. Under den yngre fasen fanns även järnframställning $i$ ett område i nordväst. Illustration: Marita Sjölin, Arkeologerna, Statens historiska museer. 
lagning i samband med förrådshushållning och hantverk av olika typer inklusive järnframställning men här har också funnits en byggnad som fungerat som bostad (figur 9).

De två treskeppiga husen låg intill varandra med nord-sydlig orientering och parallellt med bäcken. Det äldre, västra huset C14-daterades till yngre vendeltid-tidig vikingatid. Det var $19 \mathrm{~m}$ långt och 5,5 m brett. Stolpsättningen antyder att huset kan ha varit indelat i tre rum, med centralt placerad bostads- och köksdel samt ekonomidelar i de båda gavlarna. Det östra, yngre, huset daterades till vikingatid och var det mest välbevarade av de två. Byggnaden har varit cirka $26 \mathrm{~m}$ lång och $6 \mathrm{~m}$ bred med 14 takbärande stolpar. Stolphålen var stora, kring 0,5-0,6 m i diameter, och många var skodda med slagg och rester av ugnsväggar. Huset har haft fyra avdelningar; ett centralt rum, ett rum i vardera gaveln samt ett ingångsrum norr om det centrala rummet. I det centrala rummet fanns två rader med mindre stolphål som kanske skulle kunna indikera en fähusdel. En fosfatkartering visade emellertid fläckvis låga, fläckvis förhöjda fosfatvärden i detta rum, något som talar mot en tolkning som fähus, särskilt när också spår av gödselhög utanför huset saknas (Petersson 2006:60 62). Stolparna skulle istället kunna ha utgjort stöd för väggfasta bänkar som fungerat som sängplatser (Streiffert 2005). Rummet kan därför troligen tolkas som bostad. Spår av värmekälla saknades här, liksom i resten av huset, men under denna period var det vanligt med en uppbyggd härd (så kallad eldpall). Sådana lämnar sällan arkeologiska spår i plöjd åkermark. I det norra gavelrummet fanns brända cerealier, något som möjligen kan peka mot att rummet använts för matlagning, troligen för husets innevånare. Det södra rummet saknade cerealier och ges en mera allmän tolkning som ekonomidel. I stolphålen på ömse sidor om ingången i husets norra ände fanns en del av en malstensunderliggare respektive ben från en vild fågel i storlek med en kråka. Placeringen indikerar att dessa deponerats som en form av husoffer (Carlie 2004). Vi menar att de människor som bott i denna del av storgården, varit de som utfört jordbruksarbetet, underhållit gårdens byggnader och försett människorna som bodde där med råvaror, kläder och verktyg samt konserverat födan på olika sätt $\mathrm{i}$ en tid när förrådshushållning tryggade vintern. Bäcken har markerat gränsen mellan olika sociala skikt, med ägarfamiljen på dess västra sida och arbetsfolk på den östra.

Knappt 20 m söder om långhusen och med samma orientering som dessa, har funnits två mindre ekonomibyggnader. Den ena var en tvåskeppig byggnad, cirka $12 \mathrm{~m}$ lång och $6 \mathrm{~m}$ bred, där taket burits av två inre stolpar. Mitt i byggnaden fanns en cirka $2 \times 2$ m stor lerkonstruktion, tolkad som rester efter en uppbyggd bakugn. Här framkom rikligt med brända cerealier; vete, råg och korn. Ugnen kan ha använts för brödbak - vete och råg är sädesslag väl lämpade för brödbak. Korn däremot saknar förmågan att jäsa. En möjlighet är därför att ugnen också använts för rostning av säd, något som förekom på de flesta boplatser (Petersson 2006:162-163). I byggnaden fanns även fynd av flera vävtyngder, något som visar att byggnaden använts för olika ändamål. Funktionellt ligger det nära till hands att jämföra byggnaden med grophus som ofta funnits på yngre järnålderns gårdar. Dock finns inget som tyder på att byggnaden använts som bostad. Den andra ekonomibyggnaden var enskeppig, cirka 5,5 m lång och $4 \mathrm{~m}$ bred. Byggnaden hade en ovanlig konstruktion och bars upp av parställda väggstopar. Mitt i huset, i dess längdriktning, fanns en mycket distinkt, långsmal grop som innehöll rikligt med brända cerealier av sädesslaget korn (Hordeum vulgare). Utanför huset fanns en stor grop med kraftigt upphettad skärvsten. Från Finland finns en ålderdomlig teknik belagd för att brygga öl, där man använt en urholkad trästock (Thunaeus 1968). Den långsmala gropen synes ha rymt en sådan trästock. Korn är det sädesslag som 
dominerar vid ölbryggning. Sammantaget tyder detta på att här funnits ett brygghus för ölframställning. C14-dateringar visar att båda ekonomibyggnaderna var samtida med det yngre, vikingatida långhuset. Brygghuset verkar ha funnits kvar på platsen även när övriga byggnader tagits ur bruk.

I området öster om bäcken fanns ett par blästerugnar med fynd av ugnsväggar och slagg som visar att järnframställning varit en del av gårdens ekonomi. Nära bäcken påträffades också enstaka bitar av smidesslagg. Det ska återigen framhållas att fyndmaterialet på den del av gården som låg öster om bäcken var mycket sparsamt, något som markant skiljer denna del av gården från den del som låg väster om bäcken (jfr. tabell 2).

\section{Jordbruksekonomi och markanvändning}

Åkerbruk, ängsbruk och sannolikt även bete verkar ha varit koncentrerat till själva dalgången under vendel- och vikingatid. De grödor som förekom i området öster om bäcken, och som troligen avspeglar gårdens odling, var korn (67\%), råg (15\%), havre (10\%) samt vete ( $8 \%$ ) och dessutom har man odlat lin (Sjölin 2016). Pollendiagrammet från Bredestad visar att odlingen av korn varit äldre järnålderns dominerande gröda, fortsatt i samma omfattning som tidigare, samt att odling av råg har inletts från 700-talet. Proportionerna mellan de olika sädesslagen, som de kommer till uttryck i makrofossilmaterialet, liknar andra samtida platser från östra Mellansverige (Pedersen och Widgren 1998:384). På vissa platser tolkade som elitbosättningar har dock noterats höga andelar vete (Bergström 2007), men så var alltså inte fallet i Bona. På gården har yngre järnålderns människor hållit nötkreatur, svin, får, getter, häst och tamfågel (Sjölin 2016). Proportionerna mellan de olika tamdjursslagen är osäkra, beroende på det sparsamma djurbensmaterialet. Arkeologiskt har det inte gått att belägga att djuren varit långvarigt stallade vintertid i någon av de undersökta byggnaderna. En undersökning pekar mot att utegångsdrift varit mycket viktig under äldre järnålder i västra Östergötland och liknande resultat finns från Skåne, Halland och Uppland (Tesch 1993; Carlie 1999; Petersson 2006; Göthberg 2007). Möjligen har betydelsen av utegångsdrift underskattats vad gäller yngre järnålder. Pollendiagrammet visar på en uppgång i älgört/brudört och sälg/vide under yngre järnålder, något som tyder på en röjning i våtmark, troligen för slåtter. Detta skulle kunna tala för att stallningen ökat i betydelse i Bredestadsdalen vid denna tid, men eftersom inga av de undersökta husen tycks ha använts som fähus kan det istället tala för slåtter för stödutfodring vintertid vid utegångsdrift. Placeringen av en storgård i det aktuella området med omfattande sidvallsängar kring bäcken, visar kanske hur viktig just ängsmarken var för gårdens lokalisering.

\section{En storgård under yngre järnålder - sammanfattning}

I presentationen ovan finns ett flertal punkter som talar för att Bona under yngre vendeltid och vikingatid varit en storgård, där en lokal elit bott och verkat:

- Gårdens placering i landskapet: En ny plats i landskapet togs i anspråk och inga andra samtida gårdslägen tycks finnas i området. Gården placeras i dalbotten intill ett vattendrag. Terrängläget är okaraktäristiskt för tidigare perioder. Platsens kommunikativa kvalitéer är påtagliga; flera vägar sammanstrålar här. Huvudbyggnaden var också placerad på ett sätt som inneburit maximal exponering från flera vägar. Den har också varit placerad något högre än gårdens övriga byggnader. Liknande placering av storgårdar är känt från Uppåkra och Hjärup (jfr. Hårdh 2001; Schmidt Sabo m.fl. 2011). 
- Bebyggelsens sammansättning: Gården rymde en huvudbyggnad med ett stort rum, sannolikt avsatt för mera offentliga funktioner, och likheten med vikingatidens hallbyggnader är påtaglig. Det förefaller som om denna byggnad även fungerat som bostad för den lokala elit som vi bedömer har haft sitt säte på gården. Gården har också haft ytterligare en stor byggnad, som även denna fungerat som bostad samt haft köks- och ekonomidel. Denna ersattes under vikingatid av en ny större, men i övrigt liknande byggnad. Samtidigt har också ytterligare två byggnader för olika specialiserade aktiviteter tillkommit, primärt kopplade till matberedning.

- Gårdsrummets utformning: Gården var placerad på ömse sidor om ett vattendrag. Bäcken har skilt huvudbyggnaden från gårdens övriga byggnader. Den offentliga delen av gården har varit skild från den del som kopplats till lantbruket, vardagligt hantverk och matlagning i större skala

- Flera specialiserade hantverk fanns företrädda på gården (klensmide, bronsgjuteri, möjligen pärltillverkning).

- Ett fyndmaterial med dräktdetaljer samt annan personlig utrustning av god kvalité.

- Specialiserad matberedning som brödbak, rostning av säd och troligen ölbryggning har haft så stor volym att särskilda byggnader uppförts för dessa aktiviteter. Detta antyder ett stort hushåll, sannolikt också med återkommande gästabud.

- Huvudbyggnaden har varit i bruk under en lång tid, och när den togs ur bruk övertäcktes lämningarna med ett tjockt skärvstenslager. Detta understryker byggnadens symboliska värde.

Mycket talar för att stora delar av den vendel- och vikingatida tomten övergavs i slutet av 900-talet eller början av 1000-talet e.Kr. och att bebyggelsen koncentrerades till den historiska gårdstomten intill Bredestads kyrka. Denna kan ha varit en tidigare obebyggd del av den förhistoriska gårdstomten, eller också kan här ha funnits viss bebyggelse redan tidigare. Det går därmed att argumentera för platskontinuitet vad gäller gårdstomten mellan den vendel- och vikingatida storgården och en huvudgård i ett tidigmedeltida godskomplex. Att brygghuset fortsatt använts efter att det vikingatida gårdsläget övergivits, kan ses som ett starkt argument för obruten kontinuitet mellan en vikingatida storgård och ett tidigmedeltida gods. Det tidigmedeltida godset i sin tur upplöstes i samband med agrarkrisen vid mitten av 1300-talet.

\section{Avslutande diskussion}

\section{Etablering}

I Bredestad valdes ett nytt läge i landskapet för den storgård som uppfördes vid mitten av vendeltiden. På Fyn har ny forskning visat att många historiska byar etablerades på 600talet e.Kr. (Hansen 2015). Byetableringen kopplas till introduktionen av ett nytt agrartekniskt komplex, nämligen odling av råg i mera omfattande skala och införandet av plogen (som till skillnad från årdret vänder tiltan). Till sammanhanget räknas även en ökad betoning på sädesodling. I Bredestadsdalen verkar råg ha införts under 700-talet, men i obetydlig omfattning. Årdret, inte plogen, var huvudverktyget för jordbearbetning i regionen ännu 
i slutet av 1800-talet (Erixon 1957). Möjligen har årdret varit förhärskande även i dalgångarna under yngre järnåldern.

Vi föreslår att lokaliseringen av den vendeltida etableringen i Bona istället har samband med ett annat agrarhistoriskt komplex, kopplat till djurhållningen. På sydsvenska höglandet har av tradition boskapsskötsel varit viktigare än sädesodling, och det har varit denna del av agrarekonomin som alstrat ett överskott - under medeltiden betalade man avrad (arrende) och skatt i smör, inte säd som i Sveriges spannmålsbygder. Jämfört med äldre järnålder bör emellertid spannmålsodlingen ha ökat i betydelse. En lokalisering av den nya bebyggelsen till enbart dalgången kan ur ett jordbruksekonomiskt sammanhang ha betytt att förutsättningarna för djurhållningen har varit en viktig lokaliserande faktor. Pollenanalys visar nämligen att våtmarksslåtter och röjning för detta förekommit vid upprepade tillfällen under yngre järnålder. Långlien, med blad upp till $50 \mathrm{~cm}$, är inte säkert belagd i Sverige förrän under tidig medeltid, men i norska fynd förekommer den från 700-talet och man får anta att den funnits i Sverige från samma tid (Pedersen och Widgren 1998:359). Långlien möjliggjorde slåtter i större skala, något som kan ha påverkat vinterstallningens omfattning. Janken Myrdal menar att huvudsyftet med vinterstallning är att öka mjölkproduktionen (Myrdal 1999). Vi föreslår alltså att det agrartekniska komplex som påverkat bebyggelseetableringen vid Bona inte primärt varit förbundet med sädesodling utan med husdjursskötsel.

Det förtjänar att framhållas att när den nya gården uppfördes på en tidigare obebyggd plats, skedde detta efter en uttänkt plan. Det bebyggda områdets västra del hade en mera offentlig karaktär och en mera direkt koppling till eliten, medan den östra delen var kopplad till lantbruket och driften av ett stort hushåll. Under vikingatid accentuerades gårdens betydelse i lokalsamhället. Flera nya ekonomibyggnader tillkom och ett nytt större långhus ersatte det gamla på gårdens östra del. Gårdens sammanlagda (kända) bebyggda yta gick därmed från $368 \mathrm{~m}^{2}$ till $510 \mathrm{~m}^{2}$. I Mälardalen liksom i Östergötland finns tecken på att en liknande ökning i antalet byggnader på gårdarna skett vid ungefär samman tid (Beronius Jörpeland 2010; Sköld 2012). För Bonas del bedömer vi att den vendel- och vikingatida gårdstomten bör ha omfattat cirka $13000 \mathrm{~m}^{2}$. I jämförelse omfattar den historiska gårdstomten cirka $3300 \mathrm{~m}^{2}$. På några platser som till exempel Hjärup har arkeologiska undersökningar visat att den medeltida bytomten inneburit en krympning av ett förhistoriskt bebyggelseläge (Schmidt Sabo m.fl. 2011).

Den manifesta huvudbyggnaden har tillskrivits en offentlig funktion men också stort symboliskt värde. Dess arkitektur och placering, med maximal exponering mot en väg, talar för att det var särskilt denna byggnad som kommunicerat ägarnas status och inflytande, något som även skett $\mathrm{i}$ det stora halliknande rummet $\mathrm{i}$ byggnadens mitt. Byggnaden verkar också ha varit förbunden med en rituell aspekt. Den har fortlöpande reparerats och förefaller ha varit i bruk under 350 år. Med tiden har den speciella byggnaden kommit att kommunicera att anspråken vilar på en lång hävd. Ägarfamiljens makt och inflytande i lokalsamhället bedöms ha haft sin grund $\mathrm{i}$ kontrollen av jordbrukets resurser $\mathrm{i}$ den södra delen av Bredestadsdalen. Trots det har den del av storgården som varit förbunden med gårdens drift och jordbruksekonomin inte haft samma symboliska värde och byggnaderna här underhölls inte på samma sätt som huvudbyggnaden.

Ett möjligt scenario i Bona är att huvudbyggnaden med sitt stora centrala rum tas ur bruk när en kyrka byggs på platsen. Denna första kyrka har sannolikt varit av trä och uppförts som en gårdskyrka. Kyrkan har då i viss mån tagit över den gamla huvudbyggnadens funk- 
tion som en plats där särskilda ritualer genomfördes. Den bör också ha tagit över huvudbyggnadens roll som en synlig symbol i landskapet, tätt förbunden med storgården och senare det tidigmedeltida godset. Man kan notera att kyrkan och den övriga gårdsbebyggelsen åtskildes av en väg, på samma sätt som den gamla huvudbyggnaden åtskilts från gårdens mera agrart inriktade delar av en bäck.

\section{Ny elit eller gammal}

Generellt ses en återhämtning och nystart efter den folkvandringstida krisen under 600-talet i stora delar av norra Europa (Hansen 2015). En omfattande samhällskris som den under folkvandringstid kan ge vissa grupper möjlighet att stärka sitt inflytande, men också ge möjlighet för nya grupper att genomdriva maktanspråk (Gräslund 2008; Reiersen 2017). I Bona valdes ett nytt läge i landskapet för den storgård som uppfördes. Detta kan vara ett argument för att det är människor ur en ny elit som stått bakom bygget, men också att bygget representerar en ny maktordning och en ny samhällsorganisation med tydligare skiktning i samhället. Som ett led i den nya elitens identitetsbygge, begravdes en ung person i anslutning till en stor grav som uppförts 300-400 år tidigare, i romersk järnålder. Det är möjligt att man på så sätt markerat en släktförbindelse med tidigare gårdsägare, oavsett om en sådan förbindelse funnits eller ej (jfr. Hållans Stenholm 2012).

I förhållande till andra undersökta samtida storgårdar som Borg i Östergötland, Slöinge i Halland, Järrestad i Skåne och Huseby i Småland (Lindeblad och Nielsen 1997; Lundqvist 2000; Söderberg 2003; Nylén och Söderberg 2009), för att nämna några, framstår gården vid Bona som mindre framträdande. Byggnaderna är mindre manifesta och diversifierade och fyndmaterialet är enklare. Trots detta framstår platsen som speciell. De drag som karaktäriserar de ovannämnda storgårdarna finns även vid Bona, om än i en mindre skala. Vår tolkning är att storgården i Bona varit en elitär miljö, som haft sin bas i lokalsamhället, men där människorna haft förbindelser även utanför det lokala. Markägandet har varit centralt och gården har utgjort basen för ägarnas makt. Gårdens ägare har tillhört en markägande släkt av storbönder. I huvudbyggnaden har ägarfamiljen bott, sannolikt tillsammans med husfolket. I långhuset öster om bäcken har gårdens arbetsfolk bott. Bland både husfolk och arbetsfolk bör ha funnits mer eller mindre avlägsna släktingar, tjänstefolk av varierande rang, varav vissa får antas ha varit ofria (Brink 2012). Att ägarfamiljen även haft betydelse utanför lokalsamhället understryks av gårdens kommunikativa läge. För ett regionalt inflytande talar också faktum att tingsplatsen för Vedbo härad och därtill kopplad avrättningsplats, legat inom Bonas ägor. Medeltida tingsplatser har ibland kunnat visas gå tillbaka till förhistorisk tid (jfr. Elfstrand 1998; Sanmark m.fl. 2004).

Frågan om det fanns en kontinuitet mellan vikingatidens stormannaklass och den tidigmedeltida aristokratin är mer svårbesvarad. Raseringen och övertäckandet av den yngre järnåldersgården kan tolkas på olika sätt. Å ena sidan kan den markera ett maktövertagande av nya människor, å den andra som en händelse som mer har att göra med religionsskiftet då kulten i långhuset upphörde.

\section{Kontinuitet in i äldre medeltid}

Den tydligaste förbindelselänken mellan den vikingatida storgården och den medeltida huvudgården är det faktum att den förra ligger på Bonas ägor, nära den historiska gårdstom- 
ten. Den historiska gårdstomten kan ha varit en del av den vikingatida tomten. Till detta kommer att Bredestads kyrka ligger på Bonas ägor.

Ytterligare en tydlig förbindelselänk finns från den arkeologiska undersökningen. Inom området öster om bäcken hade en av byggnaderna, ett brygghus, varit i bruk in på 1000-talet e.Kr, efter att all övrig vikingatida bebyggelse övergivits. Brygghuset utgör en förbindelselänk till den tidigmedeltida gården och överbryggar det skenbara glapp som finns mellan vikingatid och medeltid. Gårdsbebyggelsens centrum bör ha flyttat från det vikingatida läget till en närbelägen plats, som legat så nära att brygghuset fortfarande legat inom räckhåll. Vår bedömning är att den platsen varit den historiska gårdstomten.

Analysen av de historiska kartorna, de skriftliga källorna samt ortnamnen visar att Bredestad under äldre medeltid utgjorde en by med en glest grupperad bebyggelse. Bona och Munkagård var huvudgårdar i var sitt tidigmedeltida godskomplex. Under huvudgårdarna fanns både bondgårdar och torp. Möjligen har de två godsen ursprungligen utgjort ett, som benämnts Bredestad och där Bona varit huvudgård. Under äldre medeltid omfattade Bredestad, som då innehöll två huvudgårdar med underlydande enheter, ungefär 6,8 $\mathrm{km}^{2}$ (jfr. figur 6). Under förutsättning att byarnas ägogränser etablerats i vendeltid under 600-talet e.Kr, i likhet med förhållandena på Fyn (Hansen 2015), kan detta mycket väl vara ett mått även på den vendel- och vikingatida storgårdens markinnehav.

Om så är fallet betyder det att det historiska kulturlandskapet blir viktigare än vi hittills förstått för att studera yngre järnålderns landskap, markanvändning och jordägande. Om vårt antagande rörande yngre järnålderns ägoområde är korrekt, förefaller de perifera delarna av detta inte ha brukats som åker under perioden. Såväl bebyggelse som åkrar har varit koncentrerade till dalgången. Detta är något som skiljer sig från förhållandena på det medeltida godset, under efterföljande period, då mindre brukningsenheter, sannolikt underlydande torp, har etablerats i de perifera områdena på de åsryggar och sluttningar som omger dalgången. Detta representerar ett nytt system för exploatering av ägoenheten. Området drabbas hårt av den medeltida agrarkrisen; dalgångens sidor och höjder överges åter, medan odlingen av de bördiga jordarna i dalbotten fortsätter kontinuerligt. I och med agrarkrisen, upphör storgårdsdriften och ersätts av familjejordbruk. Det är således mellan två kriser som storgården som blev en huvudgård i Bona existerat.

\section{Summary}

\section{Bona in Bredestad: From a Viking Age magnate farm to a medieval estate}

The remains of a magnate farm from the late Vendel Period and the Viking Age have recently been excavated in the parish of Bredestad in northern Småland, Sweden. Thanks to the unusually rich source material it has, moreover, been possible to reconstruct a medieval estate that existed in the parish during the Early Middle Ages. The manor on this estate was Bona, which is a stone's throw from the Viking Age farm.

This article presents expressions of power in settlement and landscape from the Vendel Period when a magnate farm was established, to its function as a manor on a major estate in the Early Middle Ages. The article thus highlights the site continuity evidenced at Bona. It also elucidates how land use interacts with changes in settlement and how it was affected during the Migration Period crisis and in the late medieval agrarian crisis. 
The study combines three different types of source material: archaeological material, evidence from early maps and written sources, and pollen analysis. The selected types of source material are complementary, mutually fertilizing each other and contributing to a deeper understanding of the place.

\section{Litteratur}

Agertz, Jan och Linnéa Varenius (red.)

2002 Om runstenar i Jönköpings län. Jönköpings läns museum, Jönköping.

Almquist, Jan Eric

1954 Lagsagor och domsagor $i$ Sverige med särskild hänsyn till den judiciella indelningen. Norstedts, Stockholm.

Ashmore, Wendy och Arthur Bernard Knapp (red.)

1999 Archaeologies of landscape: contemporary perspectives. Blackwell, Malden.

Bell, Catherine

1992 Ritual Theory, Ritual Practice. Oxford University Press, Oxford.

Berg, Johan

2003a Gods och landskap. Jordägande, bebyggelse och samhälle i Östergötland 1000-1562.

Meddelanden från Kulturgeografiska institutionen vid Stockholms universitet, vol. 120.

Stockholms universitet, Stockholm.

2003b Makten, marken, tiden och rummet: det medeltida lokalsamhällets reproduktion av makt och sociala förhållanden i två lokala gods i centrala Östergötland. I Med landskapet $i$ centrum: kulturgeografiska perspektiv på nutida och historiska landskap, redigerad av Ulf Jansson, s. 89-110. Stockholms universitet, Stockholm.

Bergström, Liselotte

2007 Gräddat: brödkultur under järnåldern i östra Mälardalen. Thesis and papers i scientific archaeology, vol. 9. Stockholms universitet, Stockholm.

Beronius Jörpeland, Lena

2010 Medeltida landsbygdsbebyggelse i Stockholms län. FoU-projekt: dnr 420-4250-2005. Riksantikvarieämbetet, Stockholm.

Beronius Jörpeland, Lena och Anton Seiler

2011 Mälbys många ansikten. En tidigmedeltida huvudgård, förhistorisk och historisk gårdsbebyggelse. RAÄ UV Rapport, vol. 57. Riksantikvarieämbetet, Stockholm.

Bonnier, Ann Catherine

1996 Kyrkorna i Dals härad. Några av landets äldsta kyrkor. I Kyrka i bruk. Meddelanden från Östergötlands länsmuseum 1996, redigerad av Gunnel Mörkfors och Anne Olsson, s. 67-84.

Östergötlands länsmuseum, Linköping.

Borg, Jan och Fredrik Engman

2003 Mitt i krysset. Inför byggandet av trafikplats och breddning av riksväg 32 i Bredestad. Bredestads socken i Aneby kommun och Flisby socken i Nässjö kommun. Arkeologisk rapport, vol. 53. Jönköpings läns museum, Jönköping.

Brink, Stefan

2012 Vikingarnas slavar: den nordiska träldomen under yngre järnålder och äldsta medeltid. Atlantis, Stockholm.

Bååth, Käthe

1983 Öde sedan stora döden var. Bebyggelse och befolkning $i$ Norra Vedbo under senmedeltid och 1500-tal. Gleerup, Lund.

Bäck, Mathias och Ann-Mari Hållans Stenholm

2012 Lilla Ullevi: den heliga platsens geografi. Riksantikvarieämbetet, Hägersten. 
Callmer, Johan och Erik Rosengren (red.)

1997 «-gick Grendel att söka det höga huset-»: arkeologiska källor till aristokratiska miljöer $i$ Skandinavien under yngre järnålder. Rapport från ett seminarium i Falkenberg 16-17. november 1995. Hallands länsmuseer, Halmstad.

Carelli, Peter

2001 En kapitalistisk anda: kulturella förändringar i 1100-talets Danmark. Lund studies in medieval archaeology, vol. 26. Almqvist \& Wiksell International, Stockholm.

Carlie, Anne

2004 Forntida byggnadskult: tradition och regionalitet $i$ södra Skandinavien. RAÄ Arkeologiska skrifter, vol. 57. Riksantikvarieämbetet, Stockholm.

Carlie, Lennart

1999 Bebyggelsens mångfald: en studie av södra Hallands järnåldersgårdar baserad på arkeologiska och historiska källor. Acta Archaeologica Lundensia Series in 8, vol. 29, Hallands Länsmuseers Skriftserie, vol. 10. Almqvist \& Wisell, Stockholm.

Cinthio, Hampus

1998 Lås och nycklar. I Eketorp III. Den medeltida befästningen på Öland. Artefakterna, redigerad av Kaj Borg, s. 229-244. Kungl. Vitterhets Historie och Antikvitets Akademien, Stockholm.

Elfstrand, Bengt

1998 Skeppsättningen vid Stångebro. Östergötland 1997/98. Meddelanden från Östergötlands länsmuseum, Linköping.

Enbäck, Berith och Ådel Vestbö-Franzén

1996 Arkeologisk utredning av ombyggnation av väg 132 mellan Aneby och Bredestad. Bredestads socken och Aneby kommun. Arkeologisk rapport 1996:10. Jönköpings läns museum, Jönköping.

Engman, Fredrik

1999 Väg 132 mellan Aneby och Bredestad. Bredestads socken i Aneby kommun, Jönköpings län. Arkeologisk rapport 1999:13. Jönköpings läns museum, Jönköping.

Ericsson, Alf

2012 Terra mediaevalis. Jordvärderingssystem i medeltidens Sverige. Sveriges lantbruksuniversitet, Uppsala.

2016 Bebyggelse och agrarhistoriska förutsättningar. I Bona - en vikingatida storgård i Bredestad, Norra Småland, redigerad av Marita Sjölin, s. 13-15. Arkeologerna, Statens historiska museer, Linköping.

Erixon, Sigurd (red.)

1957 Atlas över svensk folkkultur. 1. Materiell och social kultur. Niloé, Uddevalla.

Ethelberg, Per

2003 Det sønderjyske landbrugs historie: jernalder, vikingetid og middelalder. Haderslev Museum, Haderslev.

Gräslund, Bo

2008 Fimbulvintern, Ragnarök och klimatkrisen år 536-537 e.Kr. I Saga och sed, redigerad av Mats Hellspong, s. 93-123. Kungliga Gustav Adolfs akademien, Uppsala.

Grønnesby, Geir och Aina Heen-Pettersen

2015 Gården i yngre jernalder - et spørsmål om erkjennelse? Belyst ved utgravningen av et yngre jernalders gårdstun på Ranheim. Viking 78:169-188.

Göthberg, Hans

2007 Mer än bara hus och gårdar. I Hus och bebyggelse i Uppland: delar av förhistoriska sammanhang, redigerad av Hans Göthberg, s. 403-447. Arkeologi E4 Uppland - studier, vol. 4. Upplandsmuseet Riksantikvarieämbetet Societas Archaeologica Upsaliensis, Uppsala.

Haltiner Nordström, Susanne

2010 Grunden till en träkyrka? Arkeologisk förundersökning runt Bredestads kyrka inför dräneringsgrävning. Bredestads socken i Aneby kommun, Jönköpings län. Arkeologisk rapport 2010:03. Jönköpings läns museum, Jönköping. 
Hansen, Jesper

2015 Landsbydannelse og bebyggelsesstruktur i det 1. årtusinde - et bebyggelseshistorisk regionalstudie. Opubliserad doktorsavhandling. Syddansk Universitet, Odense.

Hansson, Martin

2001 Huvudgårdar och herravälden. En studie av småländsk medeltid. Lund studies in medieval archaeology, vol. 25. Almqvist \& Wiksell International, Stockholm.

Hedvall, Richard

2009 Kyrklig etablering och expansion i västra Östergötland. I Skuggor i ett landskap. Västra Östergötlands slättbygd under järnålder och medeltid, redigerad av Anders Kaliff, s. 246-288. RAÄ Arkeologiske undersökningar Skrifter, vol. 75. Riksantikvarieembätet, Linköping.

Herschend, Frands

1993 The Origin of the Hall in Southern Scandinavia. Tor 25:175-199.

Hållans Stenholm, Ann-Mari

2012 Fornminnen: det förflutnas roll i det förkristna och kristna Mälardalen. Vägar till Midgård, vol. 15. Nordic Academic Press, Lund.

Hårdh, Birgitta (red.)

1999 Fynden i centrum: keramik, glas och metall från Uppåkra. Acta Archaeologica Lundensia, Series in $8^{\circ}$ Uppåkrastudier, vol. 30. Almqvist \& Wiksell International, Stockholm.

2001 Uppåkra: centrum och sammanhang. Acta Archaeologica Lundensia, Series in $8^{\circ}$ Uppåkrastudier, vol. 34. Almqvist \& Wiksell International, Stockholm.

2003 Fler fynd i centrum: materialstudier i och kring Uppåkra. Acta Archaeologica Lundensia, Series in $8^{\circ}$ Uppåkrastudier, vol. 45. Almqvist \& Wiksell International, Stockholm.

Häggström, Leif

2005 Landskapsutnyttjande, bete och odling på sydsvenska höglandet under äldre järnålder. Exemplet Öggetorp. GOTARC. Series B, Gothenburg archaeological theses, vol. 34. Jönköpings läns museum, Göteborg.

Jansson, Kristina och Anna Kristensson

2004 Knutpunkt Bredestad. Undersökning av järnåldershärdar och ett vikingatida hus, fornlämningarna 76 och 78, Bredestad socken i Aneby kommun, Jönköpings län. Arkeologisk rapport 2004:36. Jönköpings läns museum, Jönköping.

Jansson, Kristina och Karin Nordström

2000 Arkeologisk förundersökning. Härdar i Bredestadsdalen - inför breddning av väg 132 mellan Aneby och Bredestad. Bredestad socken i Aneby kommun, Jönköpings län. Arkeologisk rapport 2000:7. Jönköpings läns museum, Jönköping.

Jansson, Kristina och Ingvar Röjder

2014 Riksväg 32 genom Bredestad och Marbäck. Arkeologisk utredning och FU av Bredestad RÄ̈ nr 2:1, 26:1, 39:1-2, 53:1 och 175 samt Marbäck RÄ̈ nr 167 och 168 inför ny dragning av riksväg 32 inom Bona, Örle, Berga, Eket och Kulla, Bredestads och Marbäcks socknar i Aneby kommun, Jönköpings län. Arkeologisk rapport 2014:07. Jönköpings läns museum, Jönköping.

Jørgensen, Lars

2010 Gudme and Tissø. Two magnate's complexes in Denmark from the $3^{\text {rd }}$ to $11^{\text {th }}$ Cent. AD. I Trade and communication networks of the first millennium AD in the northern part of Central Europe: central places, beach markets, landing places and trading centres, redigerad av Babette Ludowici, s. 273-286. Theiss, Stuttgart.

Karsvall, Olof

2016 Utjordar och ödegårdar: en studie i retrogressiv metod. Acta Universitatis agriculturae Sueciae, vol. 92. Sveriges lantbruksuniversitet, Uppsala.

Kueppers Lara M., John Southon, Paul Baer och John Harte

2004 Dead wood biomass and turnover time, measured by radiocarbon, along a subalpine elevation gradient. Elektroniskt dokument, http://citeseerx.ist.psu.edu/viewdoc/ download?doi=10.1.1.475.1727\&rep=rep1\&type=pdf, besökt 30. augusti 2018. 
Lagerås, Per

1996 Vegetation and land-use in the Småland Uplands, southern Sweden, during the last 6000 years. Lunds universitet, Lund.

2007 The ecology of expansion and abandonment: medieval and post-medieval agriculture and settlement in a landscape perspective. National Heritage Board, Stockholm.

2016 Pollenanalytisk undersökning. Markanvändning och landskapsförändringar under tre tusen år: pollenanalytisk undersökning i Bredestad, Aneby kommun, Småland. I Bona - en vikingatida storgård i Bredestad, Norra Småland, redigerad av Marita Sjölin, s. 117-124. Arkeologerna, Statens historiska museer, Linköping.

Lindeblad, Karin

2008 Landskap och urbanisering. Östergötland ur ett centralortsperspektiv 700-1550. Lunds studies in historical archaeology, vol. 10. Media-Tryck, Lund.

Lindeblad, Karin och Anne-Lili Nielsen

1997 Kungens gods i Borg: om utgrävningarna vid Borgs säteri. Arkeologisk slutundersökning, Borgs säteri 6702, RAÄ 276, Borgs socken, Norrköpings kommun, Östergötland. Rapport UV Linköping, vol. 12. Riksantikvarieämbetet, Linköping.

Lantmäteristyrelsens arkiv (LSA)

2018 Lantmäteristyrelsens arkiv. Elektroniskt dokument, https://historiskakartor.lantmateriet.se/ arken/s/search.html, besökt 9. februari 2018.

Lundqvist, Lars (red.)

2000 Järnålderns centra: exempel från Halland och Västergötland. GOTARC. Serie C, Arkeologiska skrifter, vol. 35. Göteborgs universitet, Göteborg.

Myrdal, Janken (red.)

1999 Jordbruket under feodalismen: 1000-1700. Det svenska jordbrukets historia, bind 2. Natur och kultur, Stockholm.

Myrdal, Janken \& Morell, Mats (red.)

2011 The agrarian history of Sweden: from 4000 BC to AD 2000. Nordic Academic Press, Lund.

Nordström, Karin och Frands Herschend

2003 Det ideologiska inslaget i väven. I Trälar. Ofria i agrarsamhället från vikingatid till medeltid, redigerad av Thomas Lindkvist och Janken Myrdal, s. 50-76. Nordiska museets förlag, Stockholm.

Nylén, Alexandra och Bengt Söderberg

2009 Huseby i Värend. Gårdsbebyggelse från järnålder och historisk tid. Småland, Skatelövs socken, Huseby 1:1, RAÄ 437, Alvesta kommun. Smålands museum rapport 2009:26.

Riksantikvarieämbetet, arkeologiska uppdragsverksamheten, Lund.

Poulsen, Bjørn och Søren Michael Sindbæk, (red.)

2011 Settlement and lordship in Viking and early medieval Scandinavia. Brepols, Turnhout.

Pedersen, Ellen Anne och Mats Widgren

1998 Järnålder, 500 f.Kr.-1000 e.Kr. I Jordbrukets första femtusen år. 4000 f.Kr.-1000 e.Kr. Det svenska jordbrukets historia, bind 1, redigerad av Janken Myrdal, Stig Welinder, Ellen Anne Pedersen och Mats Widgren, s. 239-504. Natur och kultur, Stockholm.

Petersson, Maria

2002 Abbetorp - ett landskapsutsnitt under 6000 år: arkeologisk undersökning - Väderstadsprojektet: arkeologisk undersökning av en boplats, ett gravfält, en offerplats, stensträngar och fossil àkermark: RÄ̈ $288 \mathrm{mfl}$, Abbetorp 1:2 och 1:10, Rinna socken, Boxholms kommun, RÄ̈ $244 \mathrm{~m}$ fl, Väderstad 1:2 och 5:1, Väderstads socken, Mjölby kommun, Östergötland: dnr 421-32771997, 421-800-1998. Avdelningen för arkeologiska undersökningar. Riksantikvarieämbetet, Linköping.

2006 Djurhållning och betesdrift. Djur, människor och landskap i västra Östergötland under yngre bronsålder och äldre järnålder. Uppsala universitet. Riksantikvarieämbetet, Stockholm. 
Petré, Bo

1984 Arkeologiska undersökningar på Lovö. D. 2, Fornlämning RÄ̈ 7, Lunda. Studies in NorthEuropean archaeology, vol. 8. Almqvist \& Wiksell International, Stockholm.

Rikets allmänna kartverks arkiv (RAK)

2018 Rikets allmänna kartverks arkiv. J133-7e2i56 Ekonomisk karta. Bladnamn: 7E 2i Aneby. Utgiven 1954. Elektroniskt dokument, https://historiskakartor.lantmateriet.se/historiskakartor/ searchresult.html?series $=1 \&$ countyRAK=f\&page $=\mathrm{J} 133-7 \mathrm{E} 2 \mathrm{i} 56 \&$ archive $=\mathrm{RAK} \&$ firstMatchToR eturnRAK=1, besökt 9. februari 2018.

Riksantikvarieämbetets fornminnesinformationssystem (FMIS)

2018 Riksantikvarieämbetets fornminnesinformationssystem. Elektroniskt dokument, http://www.fmis. raa.se/cocoon/fornsok/search.html, besökt 17. augusti 2018.

Rahmqvist, Sigurd

1994 Ortnamn påverkade av administration i äldre tid. I Ortnamn värda att vårda. Föredrag från Riksantikvarieämbetets symposium Ortnamnskultur Stockholm 5-7 maj 1993, redigerad av Göran Ulfsparre, s. 105-110. Riksantikvarieämbetet, Stockholm.

1996 Sätesgård och gods. De medeltida frälsegodsens framväxt mot bakgrund av Upplands bebyggelsehistoria. Upplands fornminnesförenings tidskrift, vol. 53. Stockholms universitet, Uppsala.

Reiersen, Håkon

2017 Elite milieus and centres in western Norway 200-550 AD. Opublicerad doktorsavhandling. Bergens universitet. Elektroniskt dokument, https://bora.uib.no/handle/1956/16247, besökt 17. augusti 2018.

Roslund, Mats

2001 Gäster i huset: kulturell överföring mellan slaver och skandinaver 900 till 1300. Skrifter utgivna av Vetenskapssocieteten i Lund, vol. 92. Vetenskapssocieteten, Lund.

Sanmark, Alexandra, Eva Bergström och Kjell Persson

2004 Tingsplatsen som arkeologiskt problem, etapp 1, Aspa: arkeologisk provundersökning, forskning: RÄ̈ 62, Aspa 2:11, Ludgo socken, Nyköpings kommun. SAU Rapport, vol. 25. Societas archaeologica Upsaliensis, Uppsala.

Schmidt Sabo, Katalin, Torbjörn Brorsson och Mikael Larsson

2011 Hjärup 9:8: en vikingatida storgård samt äldre och yngre lämningar. Skåne, Staffanstorps kommun, Uppåkra socken, RÄ̈ 26:1 och 42. Detaljerad arkeologisk förundersökning (FU 2) 2009 och särskild arkeologisk undersökning (SU) 2009. Rapport 2011:113.

Riksantikvarieämbetet, arkeologiska uppdragsverksamheten, Lund.

Schück, Herman

1959 Ecclesia Lincopensis. Studier om Linköpingskyrkan under medeltiden och Gustav Vasa. Almqvist \& Wiksell, Stockholm.

Svenskt diplomatariums huvudkartotek över medeltidsbreven (SDHK)

2018 Svenskt diplomatariums huvudkartotek över medeltidsbreven. Riksarkivet. Elektroniskt dokument, http://www.sok.riksarkivet.se/sdhk, besökt 9. februari 2018.

Sjölin, Marita

2014 Inför jordvärme i Bona. arkeologisk utredning. Småland, Bredestad socken, Aneby kommun, Fastighet Bona 1:17. Rapport 2014:150. Riksantikvarieämbetet, arkeologiska uppdragsverksamheten, Linköping.

2016 Bona - en vikingatida storgård i Bredestad, Norra Småland. Småland, Jönköpings län, Aneby kommun, Bredestad socken, fastigheterna Bona 1:7 och 1:11, fornlämningarna RÄ̈ 53, 183 och 185 i Bredestad socken. Rapport 2016:81. Arkeologerna, Statens historiska museer, Linköping.

Sköld, Katarina

2012 En gård från yngre järnålder $i$ Valla. Östergötland, Linköpings stad och kommun, kvarteret Intellektet, RÄ̈ 330. Särskild arkeologisk undersökning. Rapport 2012:73.

Riksantikvarieämbetet, Arkeologiska uppdragsverksamheten, Stockholm. 
Smålands handlingar $(\mathrm{SmH})$

2018 Smålands handlingar. Riksarkivet (Kammararkivet). Elektroniskt dokument, https://sok. riksarkivet.se/?Sokord=Sten+Eriksson $+($ Leijonhufvud $) \&$ page $=15 \&$ postid=Arkis + a0974 85a-9ab7-11d5-a700-0002440207bb\&tab=post\&s=Balder, besökt 9. februari 2018.

Streiffert, Jörgen

2005 Gårdsstrukturer i Halland under bronsålder och äldre järnålder. GOTARC. Series B, Gothenburg archaeological theses, vol. 66. Riksantikvarieämbetet, Mölndal.

Sundkvist, Anneli

2001 Hästarnas land: aristokratisk hästhållning och ridkonst $i$ Svealands yngre järnålder. Occational papers in archaeology, vol. 28. Uppsala universitet, Uppsala.

Söderberg, Bengt (red.)

2003 Järrestad: huvudgård i centralbygd. Riksantikvarieämbetets förlag, Stockholm.

Tesch, Sten

1993 Houses, farmsteads, and long-term change: a regional study of prehistoric settlements in the Köpinge area, in Scania, southern Sweden. Departement of Archaeology, Uppsala University. Uppsala.

Thunaeus, Harald

1968 Från äldsta tider till 1600-talets slut. Ölets historia i Sverige, del 1. Almqvist \& Wiksell, Stockholm.

Tollin, Claes

1999 Rågångar, gränshallar och ägoområden. Rekonstruktion av fastighetsstruktur och bebyggelseutveckling i mellersta Småland under äldre medeltid. Meddelanden, vol. 101.

Kulturgeografiska institutionen, Stockholms universitet, Stockholm.

2012 Ägodomäner och sockenbildning i västra Östergötland. En rumslig studie om kyrkliga upptagningsområden och ägarförhållanden vid tiden för Alvastra klosters grundande. I Munkar och magnater vid Vättern, redigerad av Lars Ersgård, s. 263-386. Lunds studies in historical archaeology, vol. 15. Lunds universitet. Lund.

Vestbö, Ådel

1994 Arkeologisk utredning av alternativa sträckor för RV32 mellan Bredestads och Marbäcks kyrkbyar, Aneby kommun. Etapp 1. Arkeologisk rapport 1994:12. Jönköpings läns museum, Jönköping.

2006 Vägval Bredestadsdalen. Arkeologisk utredning, etapp 1, inför planerad nybyggnation av väg 32 mellan Bredestad och Marbäck, Bredestad och Marbäcks socknar i Aneby kommun, Jönköpings län. Arkeologisk utredning, etapp 1. Arkeologisk rapport 2006:89. Jönköpings läns museum, Jönköping.

Wahlberg, Mats

2003 Svenskt ortnamnslexikon. Språk- och folkminnesinstitutet, Uppsala.

Wickham, Chris

2005 Framing the early Middle Ages. Europe and the Mediterranean 400-800. Oxford University Press, Oxford.

Zachrisson, Torun

1998 Gård, gräns, gravfält: sammanhang kring ädelmetalldepåer och runstenar från vikingatid och tidig medeltid $i$ Uppland och Gästrikland. Stockholm studies in archaeology, vol. 15. Stockholms universitet, Stockholm. 